\title{
EL CONVENTO MEDIEVAL DE SAN FRANCISCO DE VIVEIRO. ANÁLISIS DEL EDIFICIO Y SU HISTORIA CONSTRUCTIVA ${ }^{1}$
}

\author{
Por \\ $M^{\mathrm{a}}$ DOLORES FRAGA SAMPEDRO
}

\section{1.- LA INSTALACIÓN FRANCISCANA EN VIVEIRO}

La tradición, recogida por los cronistas de la Orden, atribuye la fundación del convento vivariense a un fraile, considerado como discípulo directo de San Francisco de Asís, que poco tiempo antes había fundado asimismo el convento de Ribadeo (año 1214) donde permanece inhumado ${ }^{2}$. La petición de fundación fue hecha por el mismo pueblo vivariense, que solicitaría a Fr. Bernardo de Quintaval, de paso por la villa tras su visita

\footnotetext{
'Este artículo es un capítulo de mi Tesis Doctoral «Arquitectura de los frailes Menores conventuales en la Edad Media Gallega (S.XIII-XV)», defendida en Lectura pública el 10 de noviembre de 1995, en la Facultad de Geografía e $\mathrm{H}^{\mathrm{a}}$ de Santiago. Son muchas las personas a las que debo agradecer su ayuda en la elaboración de este trabajo, por la aportación de valiosos datos, sus sugerencias y su apoyo. Entre ellas debo citar a D.Eduardo Pardo de Guevara y Valdés, P. José García Oro, D. Carlos Adrán Goas, D.Manuel Vázquez Chao, y al Prof. D.Manuel Núñez Rodríguez, director de esta Tesis.

${ }^{2}$ CASTRO, M.DE (edit): Crónica de la Provincia franciscana de Santiago (12141614) por un franciscano anónimo del S.XVII. Archivo Iberoamericano, Madrid, 1971, pp. $40-41$ y 153 para la nota.
}

"CUADERNOS DE ESTUDIOS GALLEGOS", Tomo XLIV, Fascículo 109, Santiago 1997. 
al fraile fundador de Ribadeo, la instalación franciscana en Viveiro, hecho que se produce en 1219 , según J. de Castro ${ }^{3}$.

Sin embargo, es nesario hacer una relectura de los datos aportados por los antiguos cronistas de la Orden, ante su preocupación constante por adelantar la cronología de fundación de los conventos, con el fin de ligarlos a la fundación directa de San Francisco y sus discípulos, a su paso por Galicia. De este modo, García Oro, al estudiar el primer asentamiento de los frailes en la villa, considera una probable instalación muy temprana, merced al donativo de un particular de una casa o terreno donde se ubicaría la comunidad provisionalemente. Así se atestigua que en 1258 los franciscanos ya disfrutaban de «casa» en la villa ${ }^{4}$, puesto que en el Capítulo de la Orden en este mismo año, consta que los frailes se hallaban instalados en Viveiro e integrados dentro de la Custodia de Ourense ${ }^{5}$. A partir de entonces, y durante los siglos bajomedievales, los testamentos y donaciones se suceden (testamento de Pedro Abril, tesorero de la catedral de Santiago (1279) ${ }^{6}$; testamento de Esteban Galván, canónigo de Mondoñedo (1287) ${ }^{7}$; el obispo de Mondoñedo, Nuño Pérez, también les cede unas casas del cabildo en Ribadeo y $\mathrm{Lugo}^{8}$ ). Sin embargo, a pesar de esta afluencia de mandas y legados la construcción del convento e iglesia es posterior, como se expondrá en líneas posteriores.

Por otra parte a finales del S.XIII, los franciscanos son testigos, y en ocasiones también protagonistas, de la controversia entre el obispo de Mondoñedo y el concejo vivariense que pretendía desligarse del poder

\footnotetext{
${ }^{3}$ GÓMEZ PARENTE, O. (edit): J. DE CASTRO: Crónicas franciscanas de España. Salamanca 1722. Edic. facsímil de Archivo Iberoamericano. Madrid, 1976. T.I. pp. 29 y 207 para la nota.

${ }^{4}$ GARCÍA ORO, J.: San Francisco de Asís en la España medieval. Liceo Franciscano, Consejo Superior de Investigaciones Científicas. Santiago, 1988, pp. 120-121. LÓPEZ, A: La Provincia de España de los frailes menores. Santiago, 1915, p. 156.

${ }^{5}$ LÓPEZ, A.: «Memorias históricas de la Provincia de Santiago. Convento de Vivero, S. XIII-XV», en Eco Franciscano 31, 1914, pp. 498-500. CASTRO, M. DE: La Provincia franciscana de Santiago. Ocho siglos de historia. Santiago, 1984, p. 126.

${ }^{6}$ Lega «fratribus minoribus de Vivario, de crunia et de Ponte veteri X solidos». v. LÓPEZ FERREIRO, A.(edit): Galicia histórica. Colección Diplomática. Santiago, 1901, p. $239, \mathrm{n}^{\circ} 53$.

${ }^{7}$ Archivo Histórico Nacional, sec. clero, carp. 1186, $\mathrm{n}^{\circ} 8$.

${ }^{8}$ Como contrapartida beneficia al cabildo con el arciprestazgo de Lorenzana. v. CASTRO, M.DE: «Los franciscanos de Vivero y Gómez Pérez das Mariñas», en Estudios Mindonienses 5, 1989, pp.533-534.
}

"CUADERNOS DE ESTUdIOS GALLEGOS", Tomo XLIV, Fascículo 109, Santiago 1997. 
señorial de aquel para adherirse a la condición de villa de realengo, con las prerrogativas que ello suponía9. Por ello en 1290 el obispo, Alvaro Gómez, prohíbe a los vivarienses entrar en cualquier iglesia, bajo pena de excomunión. Sólo los franciscanos ofrecerán su acogida al pueblo ${ }^{10}$, a pesar de las amenazas del obispo, quien en 1293 envía una carta al guardián de San Francisco para que impidiese la entrada al templo franciscano, de los miembros del concejo de Viveiro excomulgados ${ }^{11}$. Con posterioridad, desde 1346, Viveiro logra mantener su «ilusión de ser realenga» (García Oro), merced a unas condiciones económicas idóneas ${ }^{12}$. A pesar

\footnotetext{
${ }^{9}$ GARCÍA ORO, J.: Galicia en los S.XIV y XV. T.II. La Coruña, 1987, pp.100-102.

${ }^{10}$ CAL PARDO, E.: «De Viveiro en la Edad Media», en Estudios Mindonienses 7, 1991, pp. 11-226. p. 61 para la nota. DONAPETRY IRIBARNEGARAY, J.: «Privilegios, Cédulas y Cartas Reales otorgadas a Vivero», in Boletín de la Comisión Provincial de Monumentos de Lugo T.V, $2^{\circ}$ semestre, 1953, n 40, pp. 237-253. p. 239 para la nota.

${ }^{11}$ CASTRO, M.DE: «Los franciscanos...p.534.

${ }^{12} \mathrm{La}$ villa ya gozaba del privilegio de detentar alfolí propio desde el privilegio otorgado por el monarca Alfonso X (año 1262). Asimismo gozaba en este momento de una situación económica «relativamente privilegiada, especialemente por lo que toca a las rentas del protazgo, a las multas y los impuestos que gravaban a los labradores de la villa», y además, en lo referente al puerto y la pesca. v. GARCIA ORO, J.: Galicia en los siglos... T.II. p. 101. Durante las luchas trastamaristas, la villa se decanta por la facción petrista, por lo que el monarca le otorga rápidamente privilegios, como la exención del cobro del diezmo de las vituallas que acudiesen al mercado en 1357, la ampliación de su alfoz en 1368. Viveiro se mantiene fiel hasta la muerte del monarca. Tras este suceso el rey Enrique II confirma, en 1371, al obispo mindoniense su poder para elegir alcaldes anualmete en Viveiro, con lo que implícitamente reconoce el señorío episcopal sobre la villa, aunque ya desde finales del S.XIV y durante el S.XV, de nuevo aparecen los privilegios reales y los representantes de la monarquía en la villa. v. GARCÍA ORO, J: Viveiro en los S.XIV y XV. Colección Diplomática de Santo Domingo de Viveiro. Publicación del Exmo. Aytmo. de Viveiro. Viveiro, 1988, pp. 14-23. Se ha hablado asimismo de un supuesto intervalo de señorío de Fernán Pérez de Andrade, sobre la villa, sin embargo, según García Oro, se desconoce un documento regio donde se mencione explícitamente a Viveiro como villa donada a Fernán Pérez. v. GARCÍA ORO, J.: Galicia en los siglos...T.II, p. 101. En este sentido sólo existe la mención de su capellán Fernando Martís que menciona el señorío del Andrade sobre la «vila da Cruña et da vila de Betaços et da Pontedeume. Et Ferrol et a Pontedeume dérallas el rrey por sua herdade. Et outrossy tabén era señor de Neda et de Çedeyra et de Santa Marta et de Viveyro et de Vilalva, et de todos seus térmiños de todas estas vilas et lugares, et tabén das terras chaas en todas estas comarquas, en gisa que quantos homes moraa en tódaslas ditas vilas, boos et lygeyros et...». v. LORENZO, R.: Cronica Troiana. Fundación «Pedro Barrié de la Maza». Colección de Documentos Históricos. La Coruña, 1985, p. 747.
}

"CUADERNOS DE ESTUDIOS GALLEGOS", Tomo XLIV, Fascículo 109, Santiago 1997. 
de ello, las relaciones con el obispo no deben ser cordiales, y de ahí la necesidad de una reunión celebrada, en abril de 1349, «enno moesteyro de San Francisco», entre el obispo Alfonso Sánchez y el concejo, para establecer una Concordia por la cual el Concejo de Viveiro «se compromete a retirarse de las tierras que habían sido del obispado y catedral de Mondoñedo y de la casa-torre de Gerdiz» y el obispo, Alfonso Sánchez, acuerda «levantar la excomunión y entredicho que pesaba sobre la villa de Viveiro» ${ }^{13}$. Este acuerdo es la constatación de la labor de los frailes como mediadores en los conflictos de la localidad, pero también de la existencia de un monasterio franciscano, probablemente ya construido en esta fecha de $1349^{14}$.

Por otra parte, los propios frailes mantendrán a lo largo del S.XIV, disputas con las parroquias de Santiago y de Santa María en la misma villa, así como con los dominicos, también asentados en la ciudad desde el tercer cuarto del S.XIII ${ }^{15}$. El problema con sus hermanos Mendicantes surge por el asentamiento de las monjas dominicas en el radio de acción de los franciscanos ${ }^{16}$. La bula de Gregorio XI, Exhibita nobis, intenta

${ }_{13}$ Archivo Catedralicio de Mondoñedo. Arm. 3, n. 9/1, Calendario I, fol. 159r-v. Transcr: XVIII, fols. 218v-220v. Transcripto en CAL PARDO, E.: «De Viveiro en la Edad Media», en Estudios Mindonienses 7, 1991, pp. 11-226, n 47, pp. 134-138 para la nota.

${ }^{14}$ El documento especifica claramente «commo nos, o Conçello de Viveyro, seendo en conçello enno moesteyro de San Francisco desse lugar» (...) «mandamos delo faser duas cartas en hun tenor, tal hua commo a outra, por (...), feytas enno moesteyro de San Francisco deste lugar de Viveyro, treçe dias de abril, era de mill et tresentos et oytenta et sete annos», en IBIDEM, pp. 134-135.

${ }^{15}$ Parece que la consolidación de los dominicos en la villa es rápida, puesto que en 1285 ya tiene una comunidad consolidada y «recibe donaciones testamentarias con regularidad en los dos últimos decenios del siglo. En los mismos años ochenta se puede comprobar el significado social y econlómico de la comunidad dominicana que es agraciada por Sancho IV, el 12 de diciembre de 1288, con la concesión de amplias franquicias en los portazgos, alcabalas y otros impuestos vigentes en la villa». v. GARCIA ORO, J.: Viveiro en los Siglos... p. 28 para la nota.

${ }^{16}$ Sobre derechos de asentamiento y legislación entre los Mendicantes, con el objetivo de respetar y evitar inmiscuirse en el radio de acción (por cuanto podría redundar en una merma de los beneficios en las donaciones, mandas testamentarias, etc.),v. LE GOFF: «Apostolat mendiant et fait urbain dans la France médiévale: l'implantation des ordres mendiants. Programme-Questionnaire pour une enquête», en Annales 1968, pp.335-352; IBIDEM: «Ordres mendiants et urbanisation dans la France médiévale. État de l'enquête», en Annales 25 année, juillet-août 1970, nº4, pp.924-946.

"CUADERNOS DE ESTUDIOS GALLEGOS", Tomo XLIV, Fascículo 109, Santiago 1997. 
pacificar los ánimos entre ambas Órdenes ${ }^{17}$. Y si bien ambas Órdenes mantienen sus recelos en esta ocasión, esta actitud no es frecuente, en vivariense, y lo habitual es que franciscanos y dominicos se querellen con los párrocos de la villa, por las prerrogativas de predicación de los Mendicantes. Los ejemplos son numerosos, los encontramos documentados durante varios años. Así en 1334, deben acudir a la intercesión del arzobispo de Santiago, Juan Fernández de Limia y éste aconseja a los párrocos respetar «los privilegios pontificios de naturaleza ministerial que tienen ambas Órdenes» y exige su cumplimiento en Viveiro ${ }^{18}$.

No descartamos asimismo la influencia, en la historia del asentamiento y construcción del recinto conventual franciscano de dos importantes acontecimientos en la villa. Por una parte, el incendio de $1381^{19}$, que probablemente obligó a una ralentización de las obras, puesto que la población afectada se vería obligada a reconstruir sus viviendas, y por otra, el enfrentamiento trastamarista, en el que Viveiro da muestras de su fidelidad al monarca legítimo. Existen datos de la impronta que este último suceso ejerció, en la historia constructiva del convento dominicano en la villa, puesto que su situación lindante con la muralla, podría servir de baluarte en una probable contienda ${ }^{20}$, en una villa recelosa de ser «tomada et abatida $\gg^{21}$. Fue por ello que, en 1356, los frailes dominicanos acuerdan su derribo con el Concejo ${ }^{22}$.

\footnotetext{
${ }^{17}$ Para la lectura de la Bula, v. Bullarium franciscanum VI, p. 510, $\mathrm{n}^{\circ} 1274$. Se desconoce el resultado del pleito, según M. de Castro, pero lo cierto es que la fundación de las dominicas se llevó a cabo en el lugar que actualmente ocupa Santa María de Valdeflores. v. CASTRO, M. DE: «Los franciscanos de Viveiro y Gómez Pérez das Mariñas», en Estudios mindonienses 5, 1989, pp. 533-586.

${ }^{18}$ Archivo del monasterio de Valdeflores de Viveiro. v. GARCÍA ORO, J.: Viveiro en los S.XIV y XV. La colección Diplomática de Santo Domingo de Viveiro. Publicación del Excmo. Aytmo. de Viveiro. Viveiro, 1988, p. 58, $\mathrm{n}^{\circ}$ 6. Otros conflictos surgen en 1340, v. IBIDEM, n 7 y 8.

${ }^{19}$ DONAPETRY IRIBARNEGARAY, J.: «Incendios de Vivero», en Boletín de la Comisión de Monumentos de Lugo T.II, $2^{\circ}$ y $3^{\circ}$ trimestres, 1945, $\mathrm{n}^{\circ} 14-15$, pp. 47-50. $\mathrm{p}$. 47 para la nota.

${ }^{20}$ MANSO PORTO, C.: Arte gótico en Galicia: los dominicos. Fundación Barrié de la Maza. La Coruña, 1993. 2 vols. T.II, p. 566.

${ }^{21}$ LÓPEZ ALSINA, F.: Introducción al fenómeno urbano medieval gallego a través de tres ejemplos: Mondoñedo, Vivero y Ribadeo. Lugo, 1977. p. 122, nota 291.

${ }^{22}$ MANSO PORTO, C.: Arte gótico... T.II, p. 564.
}

"CUADERNOS DE ESTUDIOS GALLEGOS", Tomo XLIV, Fascículo 109, Santiago 1997. 


\section{2.- EL TEMPLO DE SAN FRANCISCO DE VIVEIRO. ANÁLI- SIS DEL EDIFICIO Y SU HISTORIA CONSTRUCTIVA:}

\subsection{El ábside y la sacristía. Análisis iconográfico y estilístico}

\section{a) Análisis estilístico}

Las antiguas Crónicas franciscanas informan que en el templo medieval se hallaba inhumado Marcos Pedro o Pérez, arcediano de Mondoñedo, «debaxo de el Coro, en un arco $»^{23}$ en cuyo sepulcro se leía «HIC IACET DOMINUS MARCUS PETRI, ARCHIDIACONUS, AERA MILLESIMA, TRECENTESIMA, TRIGESIMA SECUNDA $»^{24} \mathrm{y}$ «desde el año 1294, y está esta sepultura en la capilla de la Concepción de la Madre de Dios, en la iglesia deste dicho convento, y porque ya en este año, muy de atras había tiempo, que el convento estaba edificado» ${ }^{25}$. Actualmente nada se conserva de la citada sepultura, pero entre las obras de reparación del templo, emprendidas en los años veinte de este siglo, se halló una lauda con un escudo que porta un Cordero místico, con la oriflama, como mueble. El tipo de emblema heráldico parece remitir a modelos antiguos, quizás de principios del S.XIV (Fig.1). Asimismo la aludida carta del arzobispo de Mondoñedo para que los frailes impidiesen la entrada en su iglesia a los vivarienses excomulgados para asistir al culto, nos permiten suponer la existencia de un edificio a finales del S.XIII, aunque se tratase de pequeñas dimensiones. Ambos datos nos aportan así un punto de partida para la datación del templo. Otros datos (epígrafes y algunos documentos alusivos a las obras) proporcionan las pautas para una cronología aproximada del templo. Por esta razón, es obligado mencionar, antes de comenzar el análisis del templo, aquellos datos documentales que mencionan la obra, alguna de las dependencias o incluso el monasterio.

${ }^{23}$ GÓMEZ PARENTE, O. (edit.): Jacobo de Castro: Crónicas franciscanas... p. 207.

${ }^{24}$ WADDINGO: Annales Minorum. Quarachi, 1931. T.V. p. 185. CASTRO, M.DE: «Los franciscanos de Vivero y Gómez Pérez das Mariñas», en Estudios Mindonienses 5, 1989, pp. 533-586. p. 534 para la nota.

${ }^{25}$ CASTRO, M.DE (edit): Crónica de la Provincia de Santiago... p. 153. LÓPEZ, A.: La Provincia... pp. 134-135.

"CUADERNOS DE ESTUDIOS GALLEGOS", Tomo XLIV, Fascículo 109, Santiago 1997. 


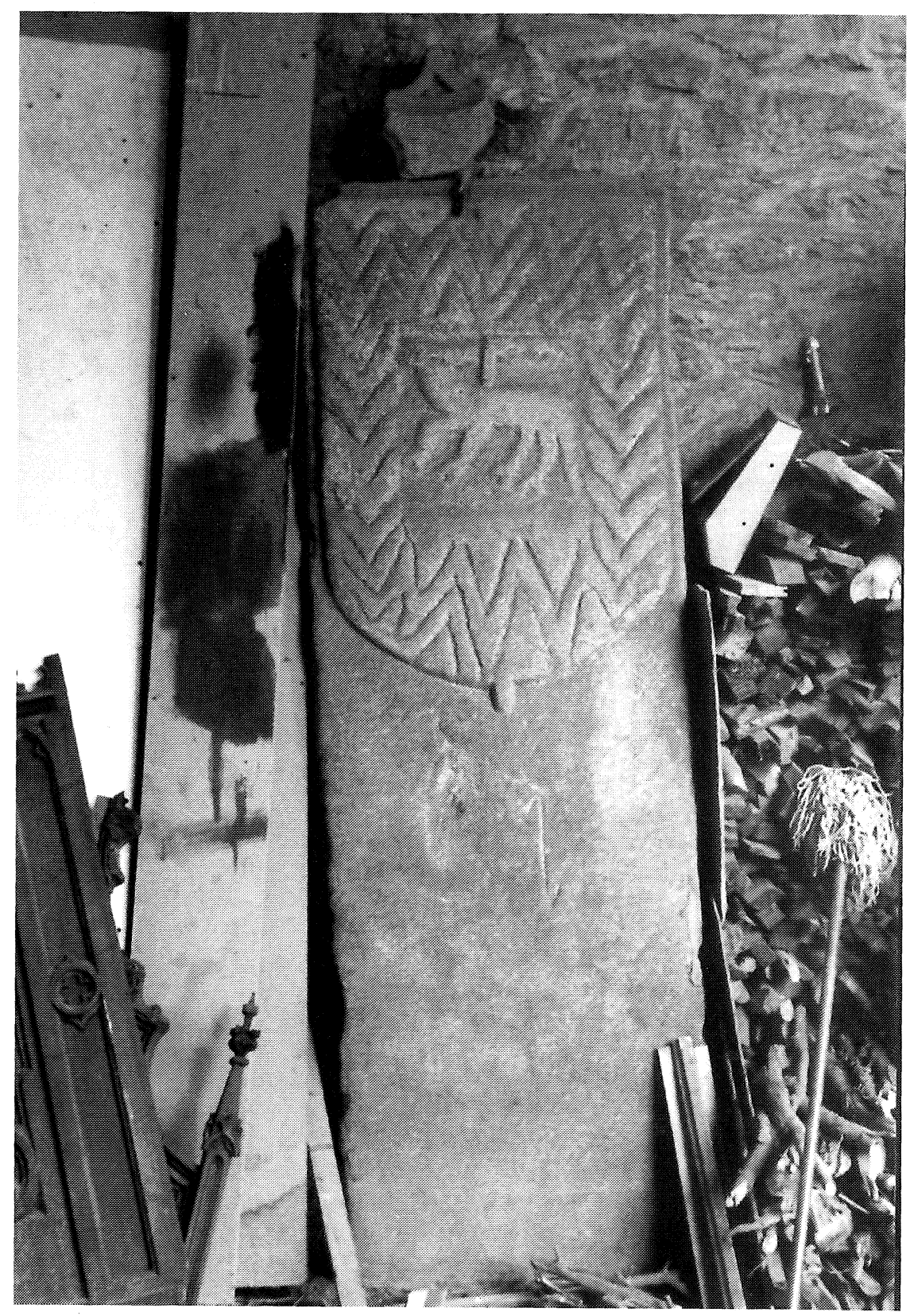

Figura 1. 
Además del citado documento del obispo de Mondoñedo en 1293, por el que se prohibía acoger en el templo franciscano a los miembros del Concejo de Viveiro; ya en la primera mitad del S.XIV, existe la mención a la «rua de San Francisco» en una donación (año 1333) ${ }^{26}$. Ambos son indicativos de la existencia de un templo franciscano a finales del S.XIII, y un asentamiento conventual consolidado a mediados del S. XIV, puesto que una calle ya se denomina con el nombre del convento franciscano. Este dato, junto con el documento que nos informa de la reunión «enno moesteyro de San Francisco», celebrada en 1349, para establecer una concordia entre el obispo Alfonso Sánchez y el concejo de Viveiro ${ }^{27}$, nos permiten señalar la existencia de un convento con las condiciones adecuadas para acoger a un número importante de personas, entre los litigantes y testigos.

En el tercer tercio de siglo, se desarrolla el pleito entre los dominicos y franciscanos por la fundación del convento femenino de la Orden de Santo Domingo, muy próximo a los franciscanos y por ello, éstos se oponen $^{28}$.

Los testamentos de los años finales del S.XIV, aluden a obras en el convento, sin especificar el objetivo exacto. Así el testamento de Alfonso Yáñez en 1387 aportaba mandas para pitanzas, lumbre y obras en los conventos vivarienses de Santo Domingo y San Francisco ${ }^{29}$, como también otro testamento, en 1391, de María Rodríguez dona veinte maravedís

\footnotetext{
${ }^{26}$ «Donación de unas casas sitas en la calle de San Francisco por el canónigo Paulucho a la catedral de Mondoñedo» en Calendario II, fol. 13r-v. Transcr.: XVIII, fols. 5v-7v, en Archivo Catedralicio de Mondoñedo, Arm. 3, n.9/2. Transcripción en CAL PARDO, E.: «De Viveiro... pp. 122-123, n 42.

${ }^{27} \ll 1349$, abril, 13. Viveiro. Traslado notarial (1351) de un conventio hecho entre el Concello de Viveiro y el Obispo de Mondoñedo don Alfonso Sánchez (1347-1366) por el que áquel se compromete a retirarse de las tierras que habían sido del obispado y catedral de Mondoñedo y de la casa-torre de Gerdiz y éste a levantar la excomunión y entredicho que pesaba sobre la villa de Viveiro», en Calendario I, fol. 159r-v. Transcr.: XVIIII, fols. 218v-220v. Archivo Catedralicio de Mondoñedo Arm. 3, n.9/1. Transcripción en CAL PARDO, E.: «De Viveiro... pp. 134-135, nº47.

${ }^{28}$ Bula de Gregorio XI «Exhibita nobis». Aviñón 2-VII-1373. v.CASTRO, M.: «Los franciscanos de Viveiro y Gómez Pérez das Mariñas», en Estudios Mindonienses 5, 1989 , pp. 533-586. p. 535 para la nota.

${ }^{29}$ Archivo Histórico Nacional, sec. Clero, carp. 1324, n. 27.
}

"CUADERNOS DE ESTUDIOS GALLEGOS", Tomo XLIV, Fascículo 109, Santiago 1997. 
para «a obra de san Francisco» ${ }^{30}$.

Durante el S.XV, continúa la sucesión de reuniones y testamentos con mandas para la obra del convento. En 1419 de nuevo se reúnen procuradores y jurados del concejo de Viveiro con el objetivo de elegir alcal$\operatorname{des}^{31}$, pocos años después en 1424, Elvira, fraira y viuda de Fernán Yáñez Vizoso y monja en Junqueira, deja unas mandas pías para la obra y alumbrado de San Francisco ${ }^{32}$.

También los frailes son beneficiarios del testamento del arzobispo de Santiago, Alvaro de Isorna en 1448, con el legado de «nosso librete pequeno das sentencias que nos dou fr. Juan de Mourence» ${ }^{33}$. Según M. Castro, este legado es el libro IV de las Sentencias de Pedro Lombardo, empleado en la enseñanza de Teología, supone la existencia de un colegio de Teología en el convento franciscano vivariense, puesto que era una obra básica en los estudios de esta disciplina ${ }^{34}$.

\footnotetext{
${ }^{30}$ «Et mando enterrar o meu corpo enno moesteiro de San Francisco de Viveiro, hu jas meu padre ou minna madre (...) Iten mando a Santa Maria de Viveiro $V^{\mathbf{o}}$ mor. para o lume. Iten outros $\mathrm{V}^{\circ}$ mor. para a obra. Iten mando para a obra de San Francisco XX mor.» V. «1391, 27 de octubre. Testamento de María Rodríguez, viuda de Pedro López Mañente, viuda de Pedro López de Mañente, por el que manda ser enterrada en el Monasterio de San Francisco de Viveiro y deja manedas para este mismo Monasterio, para el de Santo Domingo, para las iglesias de Santa María de Santiago, así como para los hospitales, cofradías y puente de la villa», en Tumbo Pechado fol. 59r. Transcr.: XVIII, fols. 93r-94v. en Archivo Catedralicio de Mondoñedo Arm. 3, n. 10. Transcripción en CAL PARDO, E.: «De Viveiro... pp. 157-160, $\mathrm{n}^{\circ} 62$.

31 «estando dentro enna iglesia do moesteiro de San Francisco da dita villa de Viveiro», v. 1419, junio, 24. Viveiro. Insistentes requerimientos del Obispo Gil Soutelo (1414-1426) al Concejo de Viveiro para que le presentase los «cobres» a fin de poder él elegir dos y nombrarlos alcaldes y reiteradas negativas del mencionado Concejo, a las que corresponde el referido Obispo con amenazas de las penas contenidas en la concordia del año 1319 e incluso de las de excomunión y entredicho», en Archivo Catedralicio de Mondoñedo Arm. 8, n. 141. Transcripción en CAL PARDO, E.: «De Viveiro... pp. $185-192, \mathrm{n}^{\circ} 76$.

${ }^{32}$ Archivo Histórico Nacional, sec. Clero, carp. 1324, n.19. Regesto en GARCÍA ORO, J.: Viveiro en los S.XIV y XV. La Colección Diplomática de Santo Domingo de Viveiro. Viveiro, 1988. p. 83, $\mathrm{n}^{\circ}$ 52. Transcripción en MANSO PORTO, C.: Arte gótico en Galicia: los dominicos. Fundación Pedro Barrié de la Maza, conde de Fenosa. La Coruña, 1993. pp.769-770.

${ }_{33}$ «Outrosi mandamos que entreguen ao Moesteyro de Sant Francisco de Vibeiro o nosso Librete pequeno das Sentencias que nos dou Fray Juan de Mourence», en «Testamento de Alvaro de Isorna (año 1448)», en LÓPEZ FERREIRO, A.: Historia de la S.A.M. Iglesia de Santiago. Santiago, 1904, T.VII. Apéndices. p. 99 para la nota.

${ }^{34}$ v. CASTRO, M.: «Los franciscanos de Viveiro... pp. 542-543.
} 
A finales del S.XV, el convento necesitaba reparaciones. Así lo declara la documentación, como veremos en 1498, y para tal fin una donación, en 1493, aporta «para la fabrica del dicho monesterio 100 reales de prata», por parte de Gómez Arias de Covelo, tesorero de la iglesia de Lugo ${ }^{35}$. Por último el documento de 1498, por el cual el Ministro provincial de la claustra, otorga la licencia al convento de San Francisco de Viveiro para vender bienes raíces en Agua Doçe, con el fin de realizar obras en las antiguas dependencias del convento, que se hallaban en mal estado y rematar las obras ya comenzadas en la iglesia ${ }^{36}$.

En planta (Fig.2), el templo franciscano de Viveiro se configura con cruz latina, de un solo ábside, sin capillas absidiales laterales, y una nave. En ésta se abren dos capillas en el lado de la Epístola. La primera es la capilla de la Orden Tercera, de fábrica moderna, y la segunda es una construcción del S.XV, de planta cuadrada. De ella se hablará posteriormente.

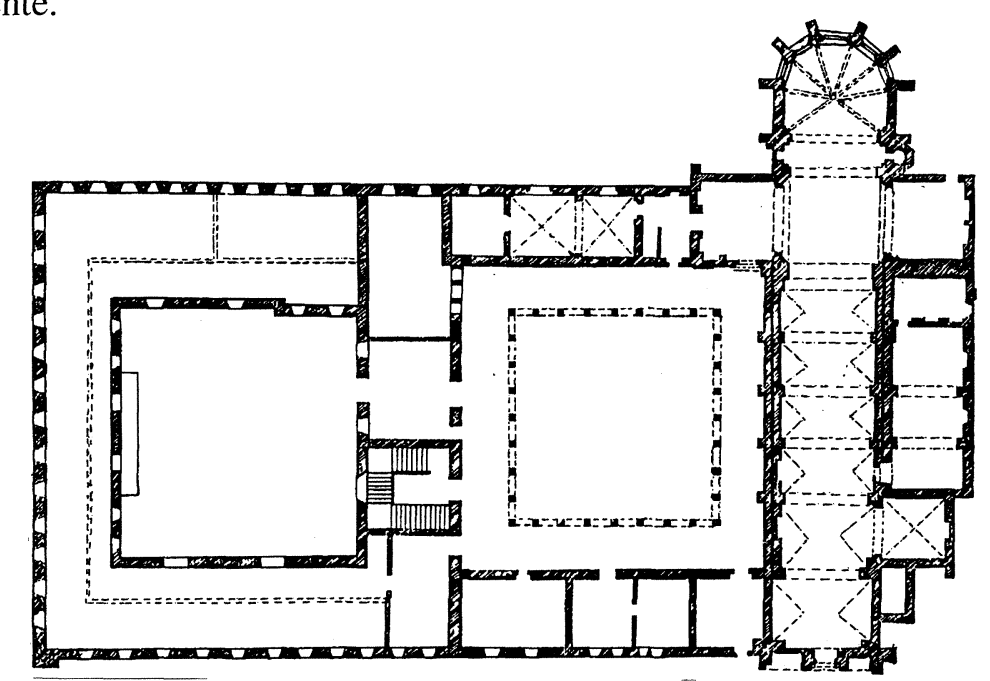

Figura 2. Plano de San Francisco de Viveiro. Según José Díaz Navarro.

${ }^{35} 1493$, noviembre 16. Vivero. Carta de contrato y arrendamiento del convento de San Francisco de Vivero, con autorización del provincial P. Juan de Carlín, por la que ceden a Gómez Arias de Covelo, tesorero de la iglesia de Lugo, unas casas en la ciudad de Lugo», en Archivo de Santa Clara de Ribadeo, caja 2. S.XV-XVI, leg. 9, fols. 1-2v. Transcripción en CASTRO, M.: «Los franciscanos de Viveiro... pp.569- 572, $\mathrm{n}^{\circ} 3$.

${ }^{36}$ Archivo Histórico Nacional, carp. 1324, n. 21. Transcripción en GARCÍA ORO, J.: Viveiro en los siglos... pp.129-130, $\mathrm{n}^{\circ} 89$.

"CUADERNOS DE ESTUDIOS GALLEGOS", Tomo XLIV, Fascículo 109, Santiago 1997. 
En alzado, a pesar de las reformas sufridas en época moderna, mantiene la estructura medieval, según típología común a los ejemplos mendicantes gallegos, aunque excepcionalmente presenta solo una capilla mayor en la cabecera ${ }^{37}$. Ésta es de planta hemidecagonal, precedida de dos tramos rectos. Se cubre con bóveda de abanico, cuyos planos verticales se horadan con óculos, tal como aparecía en las iglesias franciscanas de Betanzos o de Lugo. La bóveda se conforma con dos nervios cruceros, otro transversal, que voltean de lado a lado, mientras los dos del eje central mueren en la clave, decorada con un motivo floral, inscrito en una soga. Un segmento de arco traslada los empujes hasta la clave del arco de ingreso, en la capilla mayor. Los nervios presentan sección cuadrangular y se molduran con un grueso bocel en el intradós, flanqueado por sendas escocias en la rosca ${ }^{38}$. Por su parte, los capiteles reciben perfil gótico, tipo tronco-cónico, con astrágalo y ábaco destacados, mientras el cimacio se moldura en sendos boceles separados por una escocia, y se remata en filete, en la parte superior. Los capiteles reciben motivos de cinegéticos o de animales fantásticos, como se verá a continuación. Una línea de imposta continúa la molduración de los cimacios y une los capiteles del primer tramo recto. Las basas, de tipo ático, reposan sobre plintos cuadrangula-

\footnotetext{
${ }^{37}$ Este tipo de cabecera, con ábside único es más frecuente en los templos femeninos de los Mendicantes, tal como aparecen en Santa Clara de Pontevedra, Santa María de Valdeflores en Viveiro, y tal vez en Belvís y Santa Clara de Santiago. Sin embargo capilla mayor en los templos femeninos es de menor altura que la franciscana vivariense. EI esquema recuerda en gran medida la iglesia superior de la basílica de Asís (Italia), pero también debemos recordar que muchos de los templos franciscanos gallegos se proyectaron en un primer momento con un solo ábside, como es el caso de Betanzos, y posteriormente se añadieron las capillas absidiales ante las necesidades funerarias y devocionales. Para la tipología de los templos Mendicantes gallegos y su significación en el Gótico, v. NÚÑEZ RODRIGUEZ, M.: «La arquitectura de las Órdenes Mendicantes en la Edad Media y la realidad de la devotio moderna», en Archivo Iberoamericano T.XLXIX, 1989, n¹93-194, pp.123-139; MANSO PORTO, C.: «Orígenes de la tipología de la iglesia franciscana gallega del Siglo XIV», en Goya n²14, 1990, pp.223-226; IBIDEM: Arte gótico en Galicia: los dominicos. Fundación Pedro Barrié de la Maza, conde de Fenosa. La Coruña, 1993. 2 vol. T.I. pp.105-136 para la nota; CUADRADO SÁNCHEZ, M.: «Arquitectura franciscana en España (S.XIII-XIV)», en Archivo Iberoamericano n²01202, en-jul. 1991, pp.15-70; no 203-204, jul.-dic.1991, pp.479-551.

${ }^{38}$ La bóveda actual es una reconstrucción del año 1959, probablemente siguiendo su esquema originario. v. VÁZQUEZ CHAO, M.: «Correcciones al artículo ${ }^{\circ} 8$ de Cuadernos del Museo Mindoniense 1985». Viveiro, s.a.
}

"CUADERNOS DE ESTUDIOS GALLEGOS", Tomo XLIV, Fascículo 109, Santiago 1997. 
res, decorados con el motivo de los «colgantes» del Gótico gallego ${ }^{39}$.

El siguiente tramo recto se cubre con armazón de madera. En su alzado se descubre en el piso superior una balconada moderna, a la que se accede por medio de una escalera de caracol inmersa en una torrecilla hemihexagonal, como también aparece en el ángulo Sureste del claustro de San Francisco de Ourense, en La Coruña con planta circular, cuya finalidad es el acceso a las bóvedas del ábside para su reparación ${ }^{40}$.

La presencia de dos tramos, que preceden al ábside, posibilitando un espacio absidial mayor, relaciona este ejemplo vivariense con Santo Domingo de Bonaval, en Santiago, y con los ejemplos portugueses, donde el mayor número de frailes en el Coro (merced a comunidades más numerosas) y la financiación real de los conventos mendicantes revierte en conventos y templos de mayores dimensiones, salvo el caso de San Francisco de Porto en el que se advierte precisamente la influencia de los Mendicantes gallegos merced a un solo tramo anterior al ábside ${ }^{41}$.

El interior de la capilla mayor se ilumina por medio de cinco grandes ventanas, abiertas en los tramos del hemidecágono, amaineladas y decoradas con tracería en la parte superior por medio de dos arquillos

${ }^{39}$ Para la difusión de este motivo ornamental en el Gótico gallego, v. CAAMAÑO MARTÍNEZ, J.M.: Contribución al estudio del Gótico en Galicia (la diócesis de Santiago). Valladolid, 1962.

${ }^{40}$ Este tipo de estructura aparece en la basílica de San Francisco de Asís, flanqueando el ábside de la iglesia superior, cuya finalidad es albergar unas escaleras que faciliten la comunicación de los dos pisos. v. CADEI, A.: «L'architettura della basilica», en VV.AA.: Basilica patriarcale in Assisi. San Francesco. Testimonianza artistica. Messaggio evangelico. Fabbri Editori. Milano, 1991. pp.42-75. p.52 para la nota. IBIDEM: «Studi sulla basilica di S.Francesco ad Assisi. Architettura. (I)», en Arte Medievale IIa Sre., II1, 1988, pp. 79-103; II, II Ser., III-1, 1989, pp. 117-136. Sin embargo los dos pisos en una iglesia franciscana de Asís es excepcional, dado su denominación como «caput et mater» de toda la Orden. En Galicia estas torrecillas tendrían otra función, que podría limitarse a facilitar el acceso a las bóvedas, pero también consideramos la posibilidad de su empleo como pequeño campanario, puesto que los Estatutos de la Orden en 1260, estipulaban la elevación de pequeñas espadañas, y prohibían la construcción de grandes torres-campanario. En Viveiro, hasta el S.XVII, como se observará en líneas posteriores, los frailes no elevaron una torre-campanario. v. YARZA LUACES, J. (dir): Fuentes y documentos para la historia del Arte. Arte Medieval II. Románico y Gótico. Ed. Gustavo Gili. Barcelona, 1982. p.237.

${ }^{41}$ FRAGA SAMPEDRO, $\mathrm{M}^{\mathrm{a}} \mathrm{D}$ : Arquitectura franciscana en la antigua Custodia de Coimbra de los frailes Menores (S.XIII-XIV). Tesis de Licenciatura inédita. Santiago, 1992.

"CUADERNOS DE ESTUDIOS GALLEGOS", Tomo XLIV, Fascículo 109, Santiago 1997. 
trilobulados y coronados por un óculo central. En las cinco ventanas puede observarse una variación en los óculos desde los más sencillos con cinco lóbulos en los extremos, mientras aumentan a seis en los paños centrales. La gran originalidad de este templo la constituyen, por otra parte, la gran altura del ábside y los ventanales de mayor longitud que los ventanales de las otras iglesias mendicantes gallegas, tal vez porque la inexistencia de capillas absidiales ya desde un principio facilitaría una mayor concentración de aportes económicos y de atención a la obra del ábside, el lugar más cuidado en estos templos mendicantes. Es más el ábside vivariense presenta la originalidad de informarnos del momento en que se hace erigir, por medio de una inscripción en la jamba del último ventanal (lado del Evangelio):

ERA

MCCC

LXXXII.

TOME

Acaso se trate de la voluntad de un donante, Tomé (como J.Porben, en la inscripción que desarrollaremos a continuación, situada en el lienzo mural del Evangelio). Ambos desean dejar constancia de su participación en la obra, y del año en que ésta se ejecuta (Era de 1382, año 1344). Esta cronología, junto con la documentación y los paralelismos con la Claustra Nova y el templo franciscano ourensanos, en cuanto a iconografía (motivos cinegéticos, lucha del esciápodo y el dragón, el arquero, etc. y motivos vegetales, nos llevan a pensar que el ábside se levantaría, retomando temas de la obra catedralicia ourensana, tamizados tras la construcción del templo franciscano de Ourense (1320-1325), y por un mismo taller que se trasladó hasta Viveiro, repitiendo algunos de los temas ourensanos y que formarían parte de un repertorio de motivos al estilo del cuaderno de Villard de Honnencourt.

Por otra parte, esta inscripción, junto con el epígrafe que se engasta en el paramento murario del primer tramo recto, donde se lee:

ESTAS: SO(n): PEDR(a)S: QUE

:J: POR BE(n): MA(n)DOU: POER: XII:

"CUADERNOS DE ESTUDIOS GALLEGOS", Tomo XLIV, Fascículo 109, Santiago 1997. 
estimábamos, en líneas anteriores, aluden a dos donantes, Tomé y J. Porben, ambos pertenecientes al tercer estamento, al grupo de menestrales o profesiones liberales, puesto que su apellido, en el caso del segundo, no pertenece a la nobleza, y por otra parte ningún prócer de ese estamento privilegiado renunciaría a su distintivo heráldico. No es extraño que el pueblo colaborase en el levantamiento de un templo mendicante, en concreto de los frailes Menores, tan preocupados desde el origen de su Orden por revalorizar el trabajo manual, como un medio de Redención y no tanto de castigo, tal como se venía considerando hasta entonces ${ }^{42}$. Viveiro es además una villa que desea independizarse de todo poder señorial que lo oprime, para ligarse directamente a la figura del monarca, con el cual los lazos son más flexibles. No debemos olvidar en este sentido, los mencionados enfrentamientos con el poder señorial del obispo de Mondoñedo, de cuyo lastre deseaban desligarse los vivarienses, dado sus derechos judiciales (nombrar juez y un delegado representante de su poder), y la carga fiscal que ello conllevaba (la mitad del portazgo y la tercera parte del pedido anual, y las otras partes al $\mathrm{rey}^{43}$ ) y el Interdicto proclamado por el obispo contra el pueblo vivariense, que es acogido por los franciscanos para celebrar la Eucaristía y los demás Sacramentos. Esta adhesión de los frailes propiciaría las ayudas de los habitantes de Viveiro para la construcción del templo y probablemente del convento franciscano. Y no sólo les proporcionan las vías para satisfacer su espiritualidad, sino que también facilitan los trámites de la reconciliación con el obispo Alfonso Sánchez, ofreciendo su monasterio para la reunión entre el Concejo y el

\footnotetext{
${ }^{42}$ El mismo San Francisco aconsejaba a sus frailes que al entrar en la Orden que «trabajen y ejerzan el oficio que conozcan, siempre que no sea contra la salud del alma y pueda realizarse decorosamente. Pues dice el profeta: Comerás los frutos de tus trabajos; dichoso eres y te irá bien; y el Apóstol: El que no quiere trabajar, no coma; y también: Cada uno permanezca en el arte y oficio en el que ha sido llamado. Y por el trabajo puedan recibir todas las cosas que son necesarias, menos dinero. Y cuando sean menester, van por limosna como los otros pobres. Y puedan tener las herramientas e instrumentos convenientes para sus oficios» ( $1^{\text {a }}$ Regla, capítulo VII). Asimismo el santo consideraba, como ya lo estipulaba la regla benedictina, la necesidad del trabajo para mantener alejada a la mente de la tentaciones de la ociosidad $\left(1^{\text {a }}\right.$ Regla, capítulo VII). v. GUERRA, J.A.: San Francisco de Asís. Escritos. Biografías. Documentos de la época. Editorial Católica. Biblioteca de Autores Cristianos. Madrid, 1985. pp.96-97.

${ }^{43}$ LÓPEZ ALSINA, F.: Introducción al fenómeno urbano medieval gallego, a través de tres ejemplos: Mondoñedo, Vivero y Ribadeo. Santiago, 1976. p. 124 para la nota.
}

"CUADERNOS DE ESTUDIOS GALLEGOS", Tomo XLIV, Fascículo 109, Santiago 1997. 
obispo, en 1349, que pondrá fin a las discordias temporalmente ${ }^{44}$.

Sin embargo, parece que, en el año 1498, «muchas ofiçinas e hedefiçios del dicho monesterio estan viejas, caidas e disipadas, espeçialmente la sacrestia, spiçio, e refertorio y dormitorio, cozina e çimiterio, e otras çiertas obras estan començadas e espeçialmente el altar mayor e coro de çima (...)». Por ello la comunidad de San Francisco de Viveiro solicita licencia, al Ministro Conventual de la Provincia de Santiago, fr. Juan Carlín, para que se les permita vender bienes raíces en el lugar de Aguadoce (Viveiro), con el fin de subsanar estos gastos ${ }^{45}$. La obra del altar mayor, se refiere, probablemente, a obras de reparación o arreglo en el altar mayor, pero no ya de construcción puesto que como hemos visto el ábside estaba ya erigido desde mediados del S. XIV.

Retomando el análisis del edificio, en el ábside, una puertecilla lateral, en el segundo tramo recto que lo precede, da acceso a la antigua sacristía medieval, de la que actualmente nada se conserva. La rosca se decora con una orla de motivos cinegéticos organizados en espacios cuadrangulares, como si de viñetas se tratasen, estructura frecuente en la organización del Zodíaco medieval (Fig. 3). Se trata de representar la caza del jabalí, con despliegue de personajes (arquero, oidores, perro y juglares). La presentación se ofrece incompleta dado que la dovela de la clave y su anexa parecen la consecuencia de una sustitución en un momento ulterior y cabría pensar que en ellas se ubicasen otros personajes completando la escena, como podría ser la imagen de un caballero teniendo en cuenta que en San Francisco de Betanzos, aunque con postulados iconográficos más

\footnotetext{
${ }^{44}$ Archivo Catedralicio de Mondoñedo. Arm. 3, n. 9/1, Calendario I, fol. 159r-v. Transcr: XVIII, fols. 218v-220v. Transcripto en CAL PARDO, E.: «De Viveiro en la Edad Media», en Estudios Mindonienses 7, 1991, pp. 11-226, n 47 , pp. 134-138 para la nota. La adhesión de los vivarienses a los frailes perdura incluso en siglos posteriores, y así, en 1574, cuando «se intentó suprimir este convento y destinar su hacienda al de monjas de Santo Clara de Ribadeo, el concejo vivariense envió un peón a Salamanca donde se celebraba el Capítulo provincial, para solicitar que «dicho monasterio de San Francisco esté en pié y haya los frailes que suele haber y estar en él, atento la mucha limosna que tiene de misas e questas y otras muchas limosnas de ofrendas, con las cuales se podía muy bien mantener». v. DONAPETRY YRIBARNEGARAY, J.: Historia de Vivero y su concejo. Ed. Diputación Provincial de Lugo. Lugo, 1991 (edic. facsímil). p. 127 para la nota.

${ }^{45}$ Archivo Histórico Nacional, sec. Clero, carp.1324, nº 21. También transcripción en GARCÍA ORO, J.: Vivero en los S.XIV y XV ... pp. 129-130.
}

"CUADERNOS DE ESTUDIOS GALLEGOS", Tomo XLIV, Fascículo 109, Santiago 1997. 


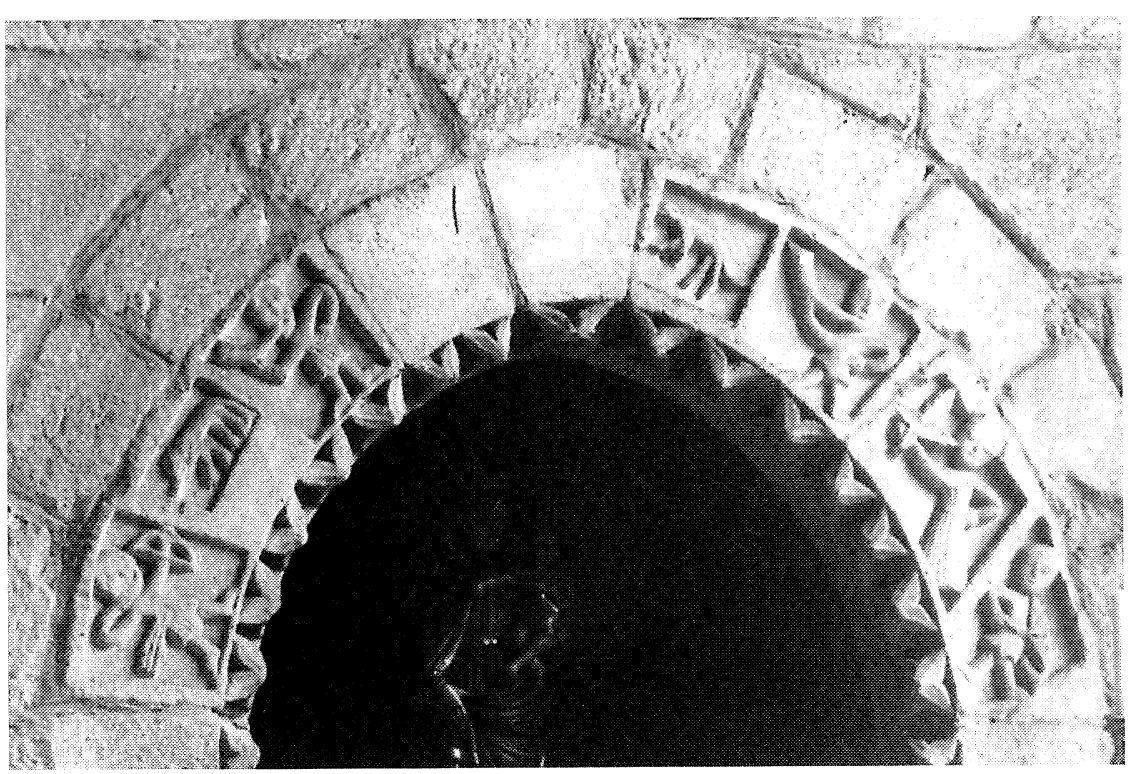

Figura 3.

concluyentes también se disponen las escenas de carácter cinegético en este punto absidial. A pesar de las incógnitas procede hacer una valoración que siempre resultaría aproximada, dando por sentado que en este templo, como en líneas posteriores se verá, el protagonismo de las escenas cinegéticas alcanza unos niveles, que sólo se ven superados por la propuesta de San Francisco de Betanzos.

En principio no parece extraño que se haya seleccionado este asunto iconográfico en el templo de San Francisco, puesto que la colaboración de miembros del pueblo vivariense en la construcción del edificio, ya fuese con donaciones, ya con su propio trabajo, probablemente condicionase en algún momento las características formales e iconográficas del templo, relegando a los frailes a simples receptores de la obra. Con este sentido, valoraremos provisionalmente las escenas cinegéticas del arco de ingreso a la sacristía, puesto que su temática era muy conocida en la vida cotidiana del vivariense: la persecución del jabalí, lobo y zorro que destrozaban sus cosechas y se comían su ganado era un suceso habitual. Para impedir que los desperfectos fuesen mayores, se organizaban cace-

"CUADERNOS DE ESTUDIOS GALLEGOS", Tomo XLIV, Fascículo 109, Santiago 1997. 
rías «defensivas», con cierta periodicidad ${ }^{46}$, en las que participaban nobleza, clero y el pueblo ${ }^{47}$, actividad que estaba codificada en los Fueros dados por el Arzobispo de Gelmírez a la Tierra de Santiago, ya en $1113^{48}$, aspecto en el que posteriormente también insistiría Berenguel de Landoira durante su episcopado $(1326)^{49}$. La existencia del reticulado para organizar las escenas, señalando la distancia entre el hombre y la fiera, puede aludir en la iglesia franciscana de Viveiro a una posible relación con otras series temáticas, como eran las representaciones zodiacales tan frecuentes en el románico hispano, pero tampoco debemos olvidar que estos motivos cinegéticos se rastrean asimismo desde obras románicas en el área castellano-leonesa ${ }^{50}$. Por otra parte, estos relieves son de factura muy tosca, e incluso inacabada puesto que la clave y la dovela más próxima se encuentran vacías. Los rasgos estilísticos tienden hacia un taller que, más que representar, presenta; es decir, desconoce el sentido de la composición de la escena para plasmar los componentes de un acto de cacería reducido a sus componentes fundamentales de manera que las figuras hermanas son verdaderos «homúnculos».

\footnotetext{
${ }^{46}$ El método más empleado en las cacerías de estas bestias era el del fogium, consistente en una batida de la zona, con gran estruendo de instrumentos, para obligar al animal a salir de su guarida en el bosque o en el monte. A continuación se acosaba a la bestia para que entrase en el fogium (dos muros de piedra o madera que se estrechaban gradualmente hasta rematar en un hoyo. v. PALLARES MENDEZ, M.C., PORTELA SILVA, E. y GELABERT GONZÁLEZ, J.: «Caza de los señores y caza de los campesinos en Galicia (1100-1600)», en La Chasse au Moyen Age. Actes du colloque de Nice (22-24 juin 1979). Publications de la faculteé des Lettres et des Sciences humaines de Nice, $\mathrm{n}^{\circ} 20$. Nice, 1980, pp. 287-301. p.289.

${ }^{47}$ En la representación vivariense llama la atención la participación del pueblo (arquero, avistador y ojeador), junto a un juglar con la juglaresa bailando. No hallamos representado al estamento noble, mientras que en otras representaciones es el más frecuente, como es el caso de los relieves y el sepulcro de Fernán Pérez de Andrade. Pero no olvidemos que en ese ejemplo brigantino, se intenta potenciar la idea de la virtus del caballero cristiano. Para este tema v. NÚÑEZ RODRÍGUEZ, M.: «El sepulcro de Fernán Pérez de Andrade en San Francisco de Betanzos como expresión de una individualidad y una época», en Bracara Augusta vol.XXXV, año 1981, pp.397-413.

${ }^{48}$ v. PALLARES MENDEZ, M.C., PORTELA SILVA, E. y GELABERT GONZÁLEZ, J.: «Caza de los señores y caza de los campesinos... p. 289 para la nota.

${ }^{49}$ IBIDEM.

${ }^{50} \mathrm{v}$. RUIZ MALDONADO, M.: El caballero en la escultura románica...pp.9, 71-74.
} 
El borde de la rosca se remata con decoración de puntas de diamante que continúan en las jambas de la puerta. La labra de las escenas se relacionan con el mismo taller que trabajó en los haces de capiteles del tramo recto, así como la decoración de puntas de diamante en borde de la jamba y del arco, como también aparecen decorando el ábaco del capitel central del lado de la Epístola (tramo recto). Obedecen pues, como aquéllos a una segunda fase constructiva del templo. Por el mencionado documento de 1498 , tenemos constancia del deterioro que sufría muchas de las dependencias del convento, «speçialmente la sacrestia», entre otras dependencias. La noticia nos confirma la hipótesis de una construcción rematada con anterioridad, puesto que a finales del S.XV ya formaba parte de las dependencias que estaban «viejas, caidas e disipadas», según se recoge en el documento.

Otro vano, de menor tamaño, se abre en el segundo paño del hemihexágono del ábside, en el lado de la Epístola. Se trata de una pequeño nicho o alacena conformada por un arquillo lobulado apuntado, que tendría la función de contener las vinajeras, como también aparece en San Francisco de Betanzos, o de Pontevedra.

\section{b) Análisis iconográfico}

En los capiteles del ábside y la rosca del arco de la sacristía descubrimos escenas cinegéticas o relacionadas de alguna manera con la caza o la lucha de animales, ya conocidos en el románico hispano ${ }^{51}$. Así en los capiteles del hemidecágono hallamos en el primero (desde la Epístola) cuatro sirenas ave en disposición seriada (Fig.4), en el siguiente la cacería de la cabra montés (Fig. 5). Ésta se dispone lateralmente, sobre ella

\footnotetext{
${ }^{51}$ Para este tema v. NÚÑEZ RODRÍGUEZ, M: «Scenes de chasse dans la peinture de l'Espagne chretienne: san Baudilio de Berlanga», en Colloque sur la chasse au Moyen Age. Université de Nice. 1979, pp.535-551; IBIDEM: «El sepulcro de Fernán Pérez de Andrade en San Francisco de Betanzos, como expresión de una individualidad y una época», en Bracara Augusta n 79-80, 1981, pp.397-410; IBIDEM: La idea de la inmortalidad en la escultura gallega (la imaginería funeraria del caballero S.XIV-XV). Orense, 1985; RUIZ MALDONADO, M.: El caballero en la escultura románica de Castilla y León. Ediciones Universidad de Salamanca. Salamanca, 1986; MANSO PORTO, C.: «Reflexiones sobre la caza nobiliaria en la Baja Edad Media y su proyección en Galicia», en Anuario Brigantino nº, 1985, pp. 9-22; IBIDEM: Arte gótico en Galicia: los dominicos. La Coruña, 1993. T.I. pp.140-141.
}

"CUADERNOS DE ESTUdIOS GALLEGOS", Tomo XLIV̀, Fascículo 109, Santiago 1997. 

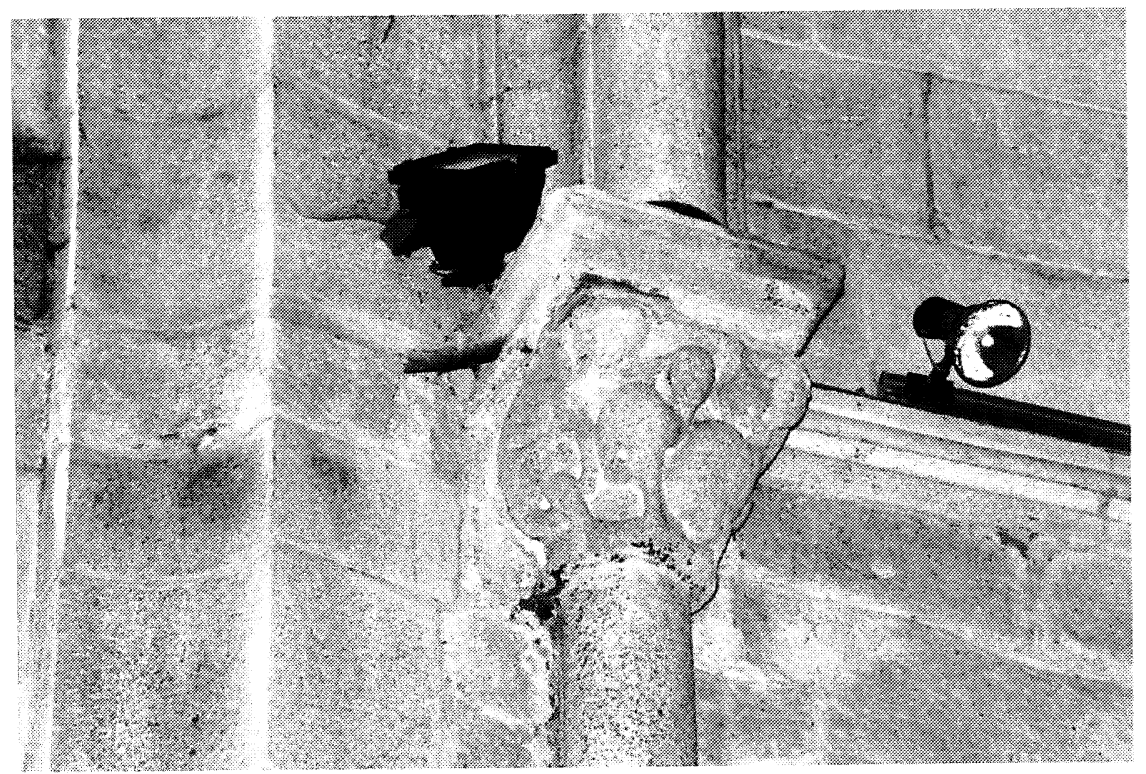

Figura 4.

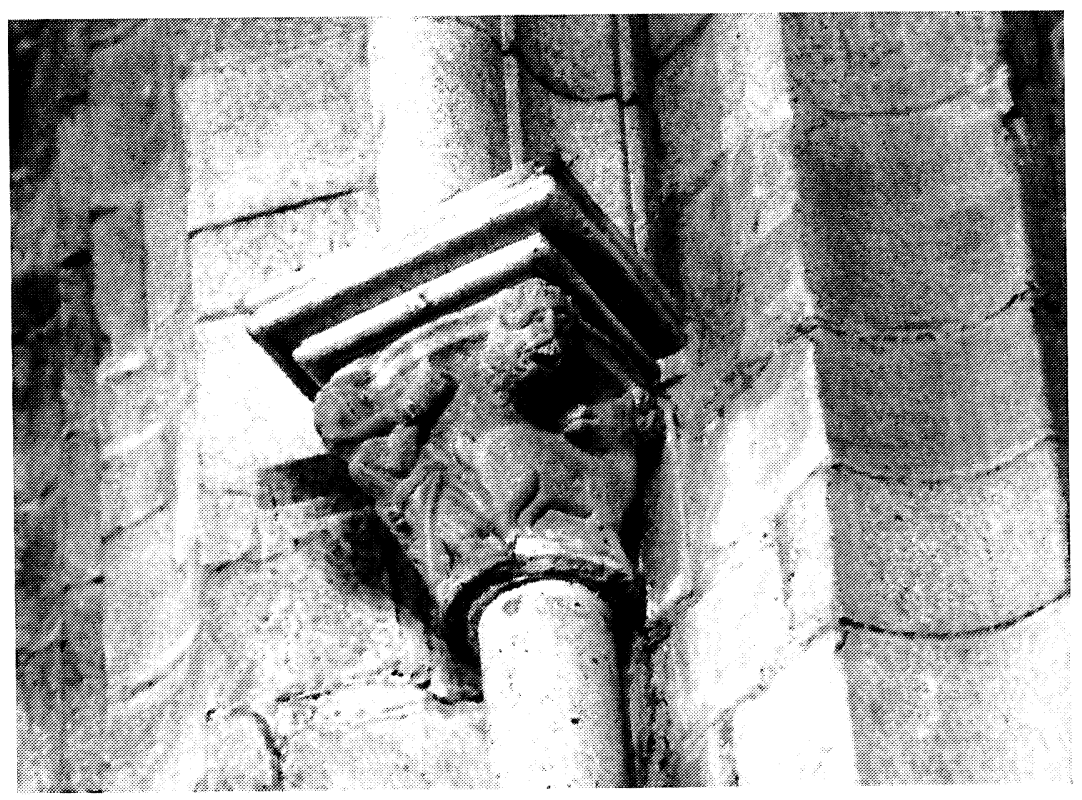

Figura 5. 
una cabeza monstruosa con la boca abierta, en actitud dispuesta a devorar a la cabra, mientras un avistador o rastreador toca la bocina anunciando que ha hallado a la presa. Sostiene a un perro de caza con la correa en la otra mano. Lleva saya corta ceñida con cinto y arco colgado del mismo, botas puntiagudas (borceguíes). La cabra montés en la Edad Media puede tener como la generalidad de los animales una doble acepción positiva y negativa. En su valoración positiva es el símbolo de Cristo, quien como «chivo expiatorio» muere por los pecados de los hombres, mientras que en su acepción negativa es un animal maligno, que se relaciona con la lujuria ${ }^{52}$. Y esta acepción es la que probablemente se le atribuyó a la cabra del capitel vivariense. Ello viene acentuado por la cabeza monstruosa que la observa desde el ángulo del capitel. Por su parte, el cazador puede aludir también a un doble significado, como los «cazadores buenos»encargados de llevar las almas al Paraíso, pero también existen «cazadores malvados», que trasladan el alma de aquellos que han pecado al infierno, según Orígenes ${ }^{53}$, o al hombre que lucha contra el pecado de la lujuria que podría representar la cabra. Y otro aspecto importante a destacar en esta figura es su gran proximidad con un cazador del claustro franciscano de Ourense (lado Oeste) que acompaña a una pareja de nobles y lleva un perro atado a una cadena ${ }^{54}$.

En el siguiente capitel (Figs.6, 7) se asiste a la lucha de una especie de centauro (al reparar en la fotografía se observará que la parte delantera invoca una forma zoomórfica que no parece corresponderse con una mutilación de la figura), en actitud de clavarle una flecha a una quimera.

${ }^{52}$ RÈAU: Iconographie de l'art chrétien. T.I. Paris, 1952, p. 87.

${ }^{53}$ FERNÁNDEZ LAGO, J.: La montaña en las homilías de Orígenes. Instituto Teológico compostelano. Collectanea scientifica compostellana. Santiago, 1993, p.118.

${ }^{54}$ Con el mismo atributo y un perro que lo acompaña, aparece un cazador en la obra románica de San Miguel de Breamo (finales del S.XII), en Puentedeume.v. YZQUIERDO PERRIN, R.: Galicia. Arte Medieval (I). Ed.Hércules. La Coruña, 1993. T.X. En obras góticas gallegas este motivo que también aparece en la capilla absidial del Evangelio en el mismo templo franciscano de Ourense, pero con otra factura más cuidada, y en los capiteles del crucero de San Francisco de Lugo, Sala capitular de San Francisco de Santiago, capilla absidial de la Epístola de San Francisco de Betanzos, entre otros ejemplos. Manso Porto, en su momento, ya aludió someramente a la influencia del claustro ourensano de San Francisco en este capitel de Viveiro. MANSO PORTO, C.: Arte gótico... T.I. p. 140 .

"CUADERNOS DE ESTUDIOS GALLEGOS", Tomo XLIV, Fascículo 109, Santiago 1997. 


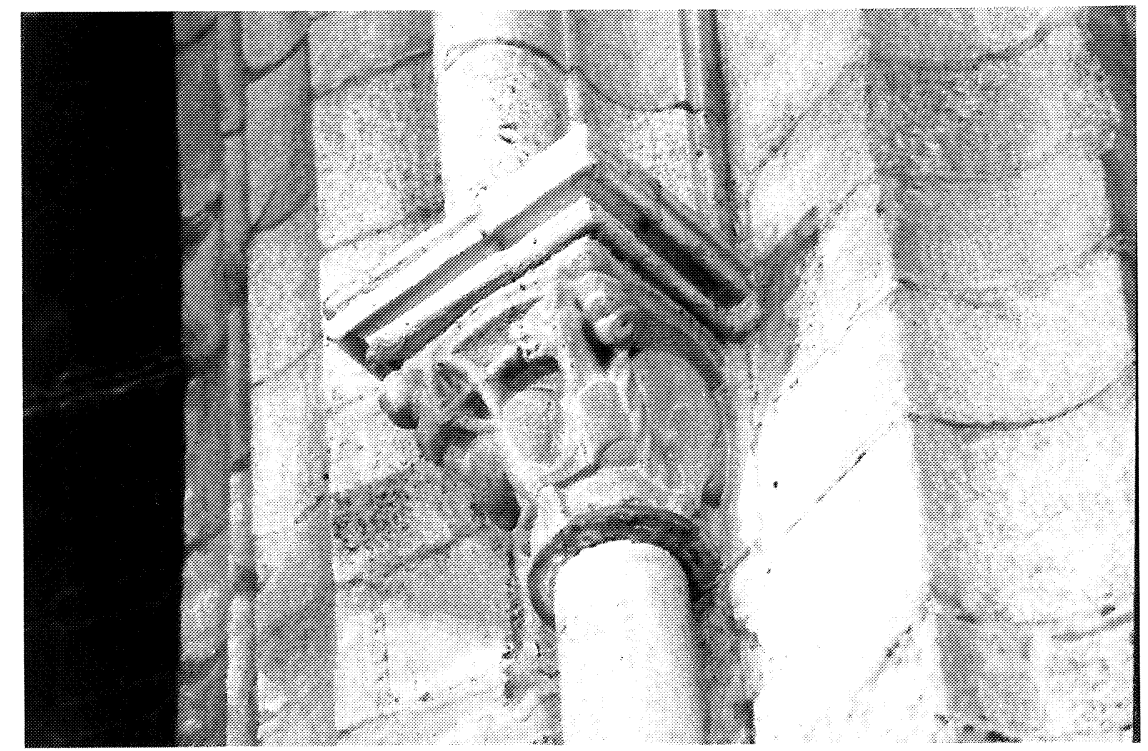

Figura 6.

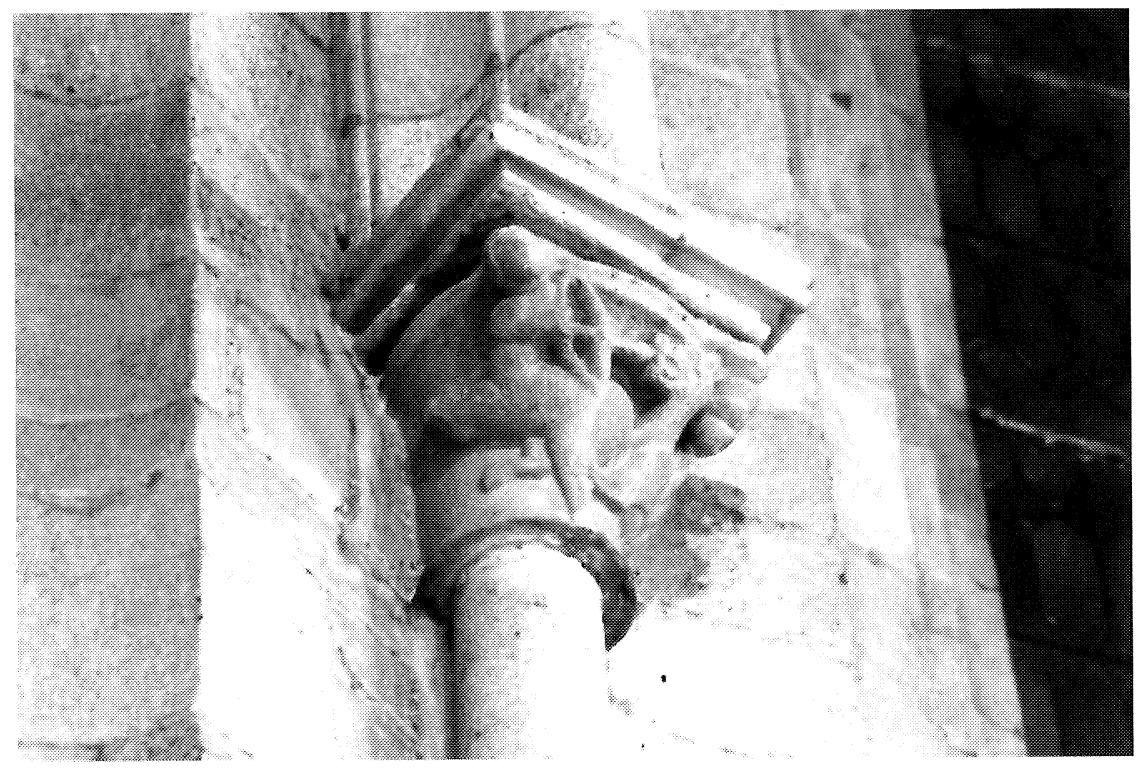

Figura 7. 
Ambos motivos, con una tradición en el románico gallego ${ }^{55}$, evidencian afinidades orientales, ya en el tema, como en el tipo de una quimera (con la cola de serpiente enroscada conformando una espiral). El centauro parece obedecer a una clase intermedia en la formación de tal ser ${ }^{56}$. Presenta cuerpo de cuadrúpedo, sin patas delanteras, y su cuarto delantero remata en una posible cabeza de bóvido, que abre su boca asustado. Del lomo sale el medio-cuerpo humano que tensa un arco en lucha contra la quimera. Ambos seres son encarnaciones malignas, uno de las pasiones y bajos instintos, de gran ferocidad, representa el lado salvaje del hombre, dado su aspecto de medio hombre, medio animal ${ }^{57}$. La quimera por su parte es encarnación del demonio ${ }^{58}$.

A continuación, de nuevo la lucha entre animales (Figs. 8, 9). Esta vez se trata del acoso a un ciervo, en la parte central, por un lobo y un oso, ambos dispuestos en las caras laterales del capitel. La escena es presenciada por dos rostros, que ocupan los ángulos, uno con expresión de terror y otro monstruoso. La contraposición del bien y mal se halla implícita en esta escena, donde el ciervo ${ }^{59}$ representa al pecador acechado por las tentaciones de la envidia $\left(\right.$ perro $^{60}$ ) y por la lujuria y

\footnotetext{
${ }^{55}$ v. YZQUIERDO PERRIN, R.: Galicia. Arte Medieval...

${ }^{56}$ Existen gran cantidad de tipos en este ser fantástico. En algunos la misma cola del cuadrúpedo es la boca del dragón contra el que luchan clavando flechas o lanzas los propios centauros. v. BALTRUSAITIS, J.: La Edad Media fantástica. (París, 1960). Madrid, 1987. pp. 141-142, lám. 95 para la nota. Asimismo v. KAPPLER, C.: Monstruos, demonios y maravillas a fines de la Edad Media. Akal Universitaria. Madrid, 1986. pp. 176ss.

${ }^{57}$ RÈAU, L.: Iconographie de l'art chrétien. Paris, 1954. T.I. pp. 118-119.

${ }^{58}$ RÉAU, L.: Iconographie... T.I. p. 115. MALAEXEVARRÍA,I.: El bestiario esculpido en Navarra. Public. del Gobierno de Navarra. Departamento de Educación, Cultura y Deporte. Pamplona, 1990. pp. 269-270 para la nota.

${ }^{59} \mathrm{El}$ ciervo tiene una significación cristológica, en base a la interpretación que proporciona el Fisiólogo, en la cual este animal es enemigo de la serpiente, imagen del demonio. Y el ciervo obliga a salir de la madriguera a la serpiente expulsando agua que lleva en su boca, como Jesús expulsa a los demonios del cuerpo de los pecadores, con su palabra. Además cuando el ciervo ha engullido una serpiente, debe beber agua rápidamente para purificarse del veneno, así los cristianos por el agua del Bautismo superan el veneno de la serpiente. v. RÈAU, L.: Iconographie pp. 82-83.

${ }^{60}$ RÈAU, L.: Iconographie... p. 183
}

"CUADERNOS DE ESTUDIOS GALLEGOS", Tomo XLIV, Fascículo 109, Santiago 1997. 


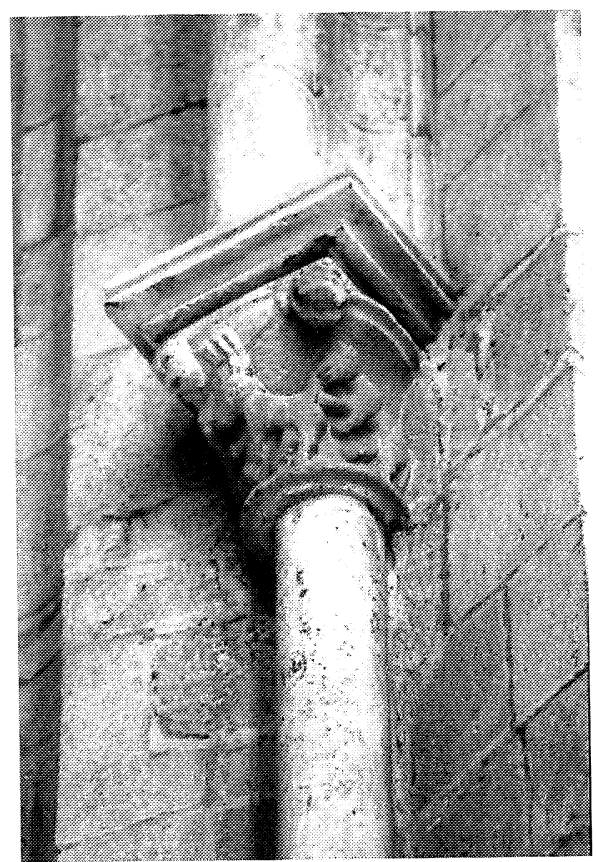

Figura 8.

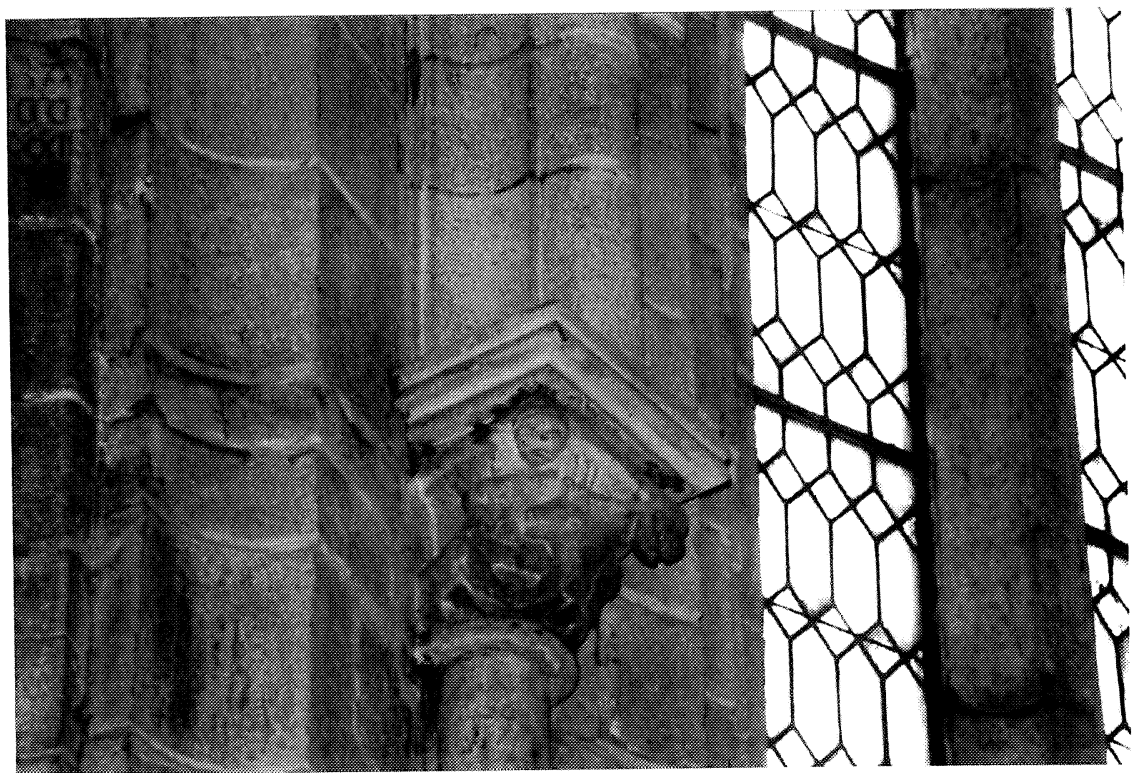

Figura 9. 
la cólera $\left(\mathrm{oso}^{61}\right)$, mientras la tendencia al bien o al mal se representa en las cabezas de los ángulos ${ }^{62}$.

El último capitel del hemidecágono ofrece la representación de tres sirenas-ave (Fig. 10). Dos de ellas comparten el mismo rostro barbado,

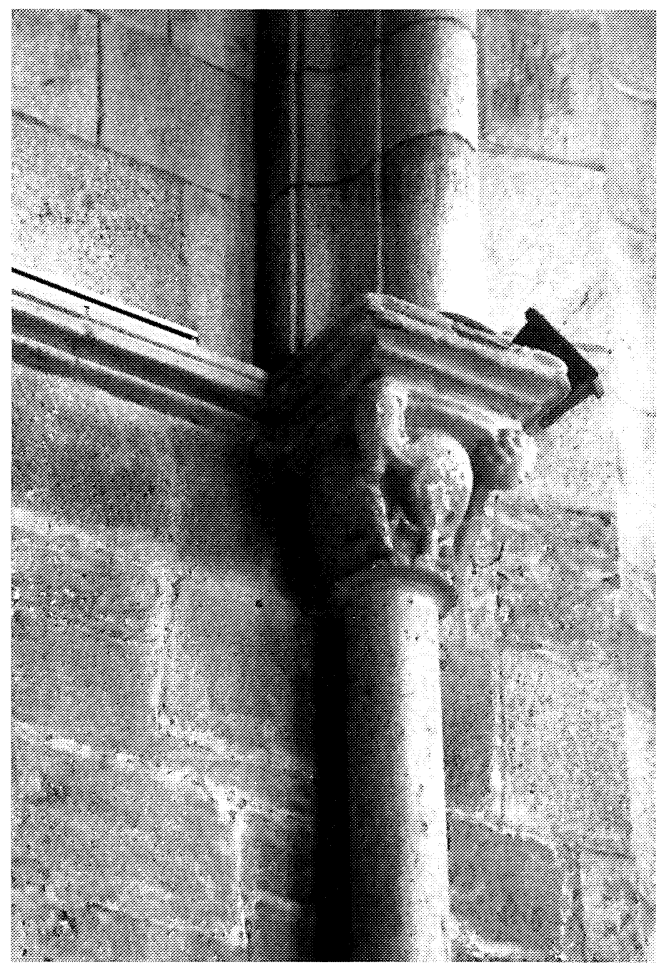

Figura 10.

${ }^{61}$ El oso es símbolo del demonio, según San Agustín «ursus diabolus». El combate victorioso de David contra el oso que diezmaba los rebaños es imagen de la lucha de Cristo contra el demonio en la tentación del desierto y el Descenso a los limbos. Es frecuente encontrar pasajes, en las vidas de los Santos, en los que éstos lo domestican como bestia de carga. Su significación negativa se relaciona con la lujuria ( «In urso caro significatur: sequitur enim mel sicut caro voluptatem» explica San Buenaventura en uno de los Sermones a él atribuídos), y con la cólera. v. RÈAU, L.: Iconographie... pp. 110-111.

${ }^{62}$ Otros ejemplos de ciervos acosados aparecen dentro de escenas cinegéticas en la capilla absidial del Evangelio de San Francisco de Ourense y en el crucero de San Francisco de Lugo, donde este tema tiene asimismo un valor moral, de exemplum (la aparición de un fraile o personajes con libros abiertos así lo sugieren). Para más información v. nota 50 de este artículo.

"CUADERNOS DE ESTUDIOS GALLEGOS", Tomo XLIV, Fascículo 109, Santiago 1997. 
tocado con bonete, mientras la otra presenta un rostro joven con cabellera rizada. Ambas recuerdan rasgos típicos de los talleres mateínos de principios del S.XIII, en los trabajos del coro catedralicio de Compostela, retomados a principios del S.XIV en la Claustra Nova ouresana. Posteriormente con ambos rostros caracterizados con barba y cabello rizado los hallamos en un capitel de la capilla del Evangelio de San Francisco de Betanzos, para representar a dos discípulos (San Juan y San Pedro) ${ }^{63}$.

El haz de tres capiteles por lado que comunican este espacio con el tramo recto se decoran en el lado del Evangelio con hojas de roble, muy semejantes a las que aparecen en algunos capiteles del arco de ingreso al ábside de San Francisco de Ourense, por influencia de la Claustra Nova, pero aquí ya ofrecen un tratamiento más tosco, lo que nos lleva a pensar en una fase posterior de la obra. Llama la atención el capitelillo frente a la nave, donde aparece la figura de un hombre tonsurado y arrodillado, sosteniendo el ábaco del capitel, a manera de los célebres atlantes (Fig. 11).

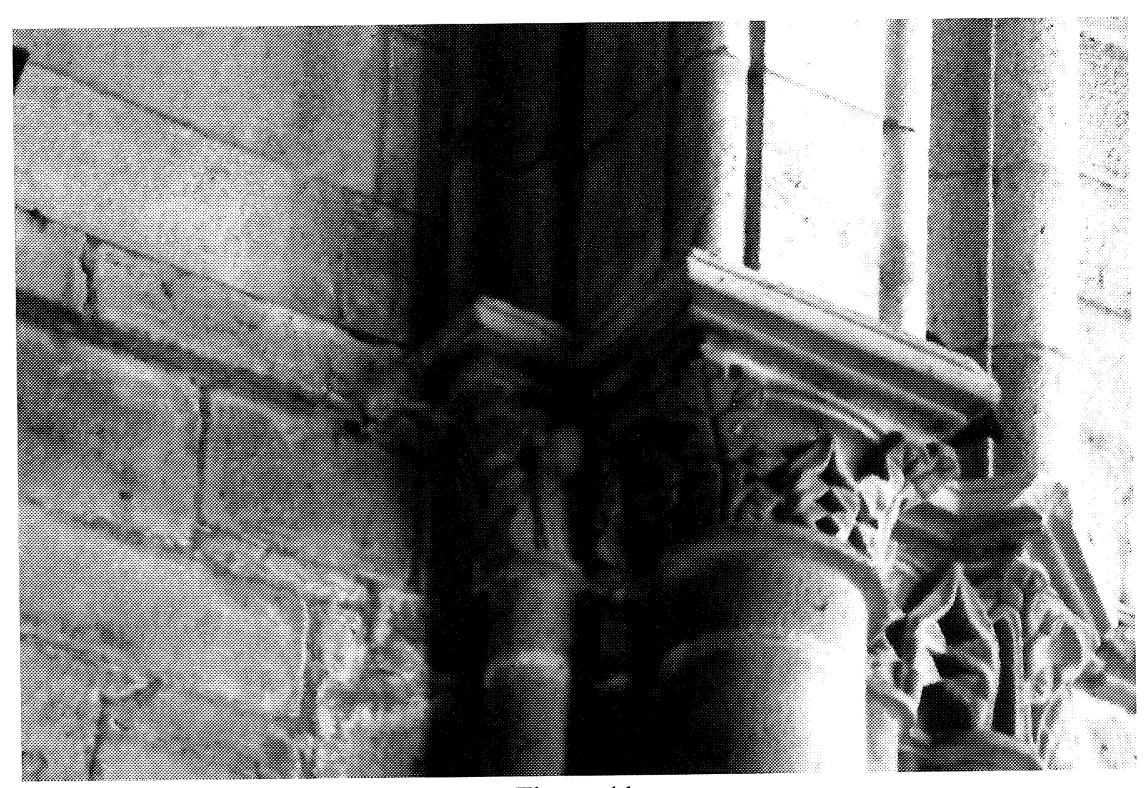

Figura 11 .

${ }^{63}$ FRAGA SAMPEDRO, M ${ }^{\mathrm{a}}$ D.: Arquitectura de los frailes Menores conventuales en la Edad Media gallega (S.XIII-XV). Tesis doctoral. Departamento de $\mathrm{H}^{\mathrm{a}}$ del Arte,

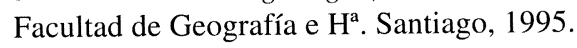

"CUADERNOS DE ESTUDIOS GALLEGOS", Tomo XLIV, Fascículo 109, Santiago 1997. 
En Galicia contamos con otros ejemplos de este motivo en el convento ourensano (arcosolio del lado de la Epístola y un capitel de la galería Oeste del claustro) retomando modelos procedentes de la catedral de Ourense (consagrado en 1188).

En el lado de la Epístola el haz se decora con dragones entrelazados y en su ábaco aparecían puntas de diamante, actualmente muy deterioradas.

La rosca del arco de ingreso a la sacristía presenta, como ya se indicó, escenas de la caza del jabalí. En la izquierda de la rosca, desde el salmer, se ordenan el juglar con un instrumento de percusión, al que acompaña una juglaresa en actitud de baile (apoya su mano izquierda en la cadera y con la derecha sostiene otro instrumento, viste sayo largo ceñido con un cinturón $)^{64}$ y por último el avistador, quien comunicaba el hallazgo de la futura presa, acompañado de un perro. En la derecha de la rosca, hallamos un arquero y un avistador con la bocina flanqueando el jabalí que va a ser rematado por el arquero que tensa ya su arma. Se trata de presentar el acto de cacería del jabalí, tal como veíamos en líneas anteriores, sin que exista otro sentido alegórico, en este caso, más allá de las imágenes ${ }^{65}$. En contraste con este relieve, el maestro o taller de los capiteles tiene un mayor conocimiento de la anatomía, de la articulación y del principio de ley de gravedad en cada una de las figuras de manera que, sin llegar a un realismo, demuestra una base informativa más elaborada, que le permite organizar las escenas conforme a un verdadero concepto de lo que es el acto o acción. No podría hablarse hasta que punto se trabaja con plantillas, pero, en cualquier caso, nunca sería un arte eidético sino fruto de una fuente directa, donde no se olvida la adaptación de la escena al marco (entiéndase el capitel) y de que el capitel deberá ser ante todo un elemento portor. Como dato complementario acaso quepa añadir que esta ico-

${ }^{64}$ La aparición de juglares con sus acompañantes, es frecuente en las escena cinegéticas del románico castellano-leonés (Hormaza en la provincia de Burgos, ex-convento de Santa María de la Vega en Salamanca, Iglesia de Nuestra Señora de la Asunción de Duratón en Segovia, iglesia de la Asunción en Perazancas (Palencia), iglesia de San Martín de Pozancos en Palencia, la iglesia de San Miguel de San Esteban de Gormaz en Soria, etc...). v. RUIZ MALDONADO, M.: El caballero en la escultura románica... pp.73,79,96-97, 100-101, 107, 108, 120-121.

${ }^{65}$ Para el desarrollo de escenas cinegéticas en el Arte y su significación, remito a la bibliografía reflejada en la nota 50 de este artículo.

"CUADERNOS DE ESTUDIOS GALLEGOS", Tomo XLIV, Fascículo 109, Santiago 1997. 
nografía queda perfectamente dispuesta al alcance del espectador sin que, como en otros casos,la temática resulte incompleta.

En conclusión, en cuanto al sentido de este conjunto iconográfico, podemos considerar que, en el ábside, el objetivo es referir la lucha del hombre contra el pecado, quizás siguiendo algún texto del que no hemos hallado rastro alguno, o tan sólo recogiendo una serie de motivos de un repertorio con una significación ambivalente, según su contexto ${ }^{66}$. Sin embargo en la puerta de la sacristía el objetivo es otro, el de presentar una serie de escenas muy familiares para los vivarienses de la Edad Media, puesto que ellos formaban parte activa, periódicamente, en estas acciones, sin olvidar que el franciscano en sus exposiciones públicas, tiende a acudir al valor de los Exempla, generalmente inspirados en la vida real, para lograr unos fines.

\subsection{El crucero}

El crucero se cubre con cúpula barroca, transformando así el antiguo armazón de madera y los arcos torales que los sustentaban en la Edad Media. No obstante todavía podemos apreciar los torales laterales, reaprovechados en los modernos. Son de sencilla sección rectangular con las aristas achaflanadas. Reposan en columnas de fustes truncados. Sus capiteles dobles reciben decoración vegetal, de castaño en los costados Este y Oeste del toral Sur y toral Norte (costado oriental); mientras que el costado occidental recibe decoración de hojas de roble. Los capiteles son góticos, con estructura semejante a los del ábside (perfil tronco-cónico, con astrágalo y ábaco acusados, el cimacio se moldura con dos boceles, separados por escocia, y remata en un fino filete). Lo más destacado, en cuanto a juegos decorativos, es la línea de imposta, moldurada de la misma forma que el cimacio en el paramento mural, que se extrae de la boca abierta de una cabeza humana (costado Oeste, toral Sur) y costado Este, toral Norte o un perro (costado Este, toral Norte). En los capiteles sólo aparece decoración figurada, con el busto de un canino, en uno de los capiteles del costado Oeste del toral meridional, semejante al capitel que

\footnotetext{
${ }^{66}$ Para una significación moral de las representaciones cinegéticas en la Edad Media, remito a la bibliografía de la nota 47 .
}

"CUADERNOS DE ESTUDIOS GALLEGOS", Tomo XLIV;; Fascículo 109, Santiago 1997. 
observamos en el interior de la capilla contraabsidial de la Epístola en la iglesia franciscana de Pontevedra. El fuste truncado de la columna remata asimismo en flores de seis pétalos inscritas en círculo, con una técnica de talla bastante elaborada, para subrayar las diferencias entre los distintos componentes vegetales ${ }^{67}$.

En cuanto al tipo de decoración vegetal de los capiteles del crucero, ésta recuerda en el toral meridional, a los capiteles del templo franciscano de Pontevedra (arco de ingreso a la capilla mayor y capilla contraabsidial de la Epístola) en las hojas picudas y la inclusión de la cabeza canina entre la decoración. Por otra parte la decoración de los capiteles del toral septentrional (costado Oeste) se halla en relación con los capiteles del arco de ingreso a la capilla mayor de San Francisco de Ourense (lado de la Epístola), ornamentado con hojas de roble, que a su vez han recogido un modelo de la Claustra Nova ourensana. En Viveiro este capitel obedece a la mano de un artista menos diestro, de ahí la tosquedad que alcanza el motivo. Al mismo artista se debe probablemente el haz de capiteles del tramo recto del ábside, lado del Evangelio. Mientras esto se observa en el costado Oeste, en el oriental se repite el esquema de los capiteles del costado meridional del crucero, más en relación con el esquema pontevedrés de hojillas picudas.

a) El hastial septentrional o capilla de la Vera Cruz ${ }^{68}$.

Los brazos del transepto se cubren con armazón de madera de parhilera con tirantes. El extremo septentrional presenta dos puertas, la occiden-

\footnotetext{
${ }^{67} \mathrm{La}$ base se decora con motivos semejantes a los que aparecen en la base de los capiteles-ménsula de la catedral ourensana. Sin embargo aunque en desde el punto de vista ornamental existan concomitancias, la función estructural de ambos es diferente, puesto que las ménsulas-capitel no poseen valor constructivo, sino meramente decorativo. v. VALLE PÉREZ, C.: «Las ménsulas-capitel en el protogótico orensano», en VV.AA.: Entorno al arte auriense. Homenaje a D.José González Paz. Universidade de Santiago de Compostela. Diputación de Ourense. Ourense, 1990. pp.43-55.

${ }^{68}$ Esta advocación aún se mantenía en 1611, según Información y autos sobre el allamiento del cuerpo de doña Constanza de Castro, difunta, y de los milagros suios (Archivo Ducal de Alba, Sec. Lemos, C-248-209). Por cita en PARDO DE GUEVARA Y VALDÉS, E.: «¿Quién era la Beata doña Constanza de Castro?. Notas críticas en torno a la discutida filiación de un personaje gallego del Siglo XV». Conferencia expuesta en Viveiro, 1991. Agradezco al autor la consulta del texto de esta conferencia, así como su trabajo acerca de la Beata vivariense, actualmente en prensa. Asimismo debo hacer constar mi gratitud por sus valiosas explicaciones en cuestiones heráldicas.
}

"CUADERNOS DE ESTUDIOS GALLEGOS", Tomo XLIV, Fascículo 109, Santiago 1997. 
tal es la antigua puerta medieval de salida al claustro (que estudiaremos en el apartado de análisis del recinto conventual), mientras la Norte fue realizada en el S.XVII, aprovechando el arcosolio medieval, que contenía el sepulcro de la Beata Constanza de Castro y Osorio. Aparece flanqueado por sendos arcosolios tambíen medievales que parecen formar parte de un conjunto funerario familiar reaprovechado, puesto que se puede observar que el arcosolio Noroccidental se reformó, ca.finales del S.XV, con la adhesión de arco conopial y dos ménsulas en cada salmer. Una de ellas presenta una ángel portador de un escudo. Es un esquema que ya se empleaba en el S.XIV, en ejemplos castellanos ${ }^{69}$. En el frente de la yacija se muestran tres divisas heráldicas. En la primera escudo divido con la representación de diferentes muebles, en jefe, un árbol, quince escaques en el centro sobre ondas en punta, sustentado por dos ángeles; en segundo lugar, un castillo sobre ondas, y por último, escudo con cinco lanzas. La factura del primer y tercer escudos nos remiten a modelos del tercer tercio del S.XV o principios del XVI.

El arcosolio contrario, al NE, (Fig. 12) presenta en su interior una yacija cubierta por tapa con una cruz, probablemente de la Orden dominica, y quizás procedentes del antiguo convento de Santo Domingo de Viveiro $^{70}$. El frente de la yacija se decora con una serie de arquillos cuyos salmeres reciben decoración de flor de lis, torres almenadas, y emblemas de bordura muy temprana (finales del S.XIII o principios del XIV) con un arbolillo como mueble heráldico.

${ }^{69}$ Llama la atención la semejanza con el arcosolio del obispo Rodrigo Díaz (+ 1339), existente en la capilla de San Martín de la catedral de Salamanca. En su yacija aparece un cortejo franciscano. En las ménsulas donde reposa el arco aparecen dos cabezas humanas, una masculina de cuya boca salen motivos vegetales, y otra femenina, que podrían atribuirse a Adán y Eva, si tenemos en cuenta que el programa se completa con la representación pictórica de la Epifanía en el fondo del arcosolio. Sobre esta representación, en la rosca del arco aparece Cristo como Varón de Dolores, flanqueado por la Virgen y San Juan. En la pared donde se halla inmerso el arcosolio se despliega un fresco del Juicio Final y en la pared lateral una serie de Santos del Antiguo y Nuevo Testamento con un epígrafe alusivo a la datación de la obra «ERA DE M CCC».

${ }^{70}$ Acerca del origen de este tipo de cruz en Galicia, en concreto en las cruces de consagración de las iglesias dominicanas de Santiago y La Coruña, v. BELTRÁN DE HEREDIA: «Origen y desenvolvimiento del stemma liliatum en las provincias dominicanas de España e Hispanoamérica», en Archivum Fratrum Predicatorum XXXV, 1965, pp. 67-84; MANSO PORTO, C.: Arte gótico en galicia: los dominicos. Fundación Pedro Barrié de la Maza, conde de Fenosa. La Coruña, 1993. T.II, p. 450.

"CUADERNOS DE ESTUDIOS GALLEGOS", Tomo XLIV, Fascículo 109, Santiago 1997. 


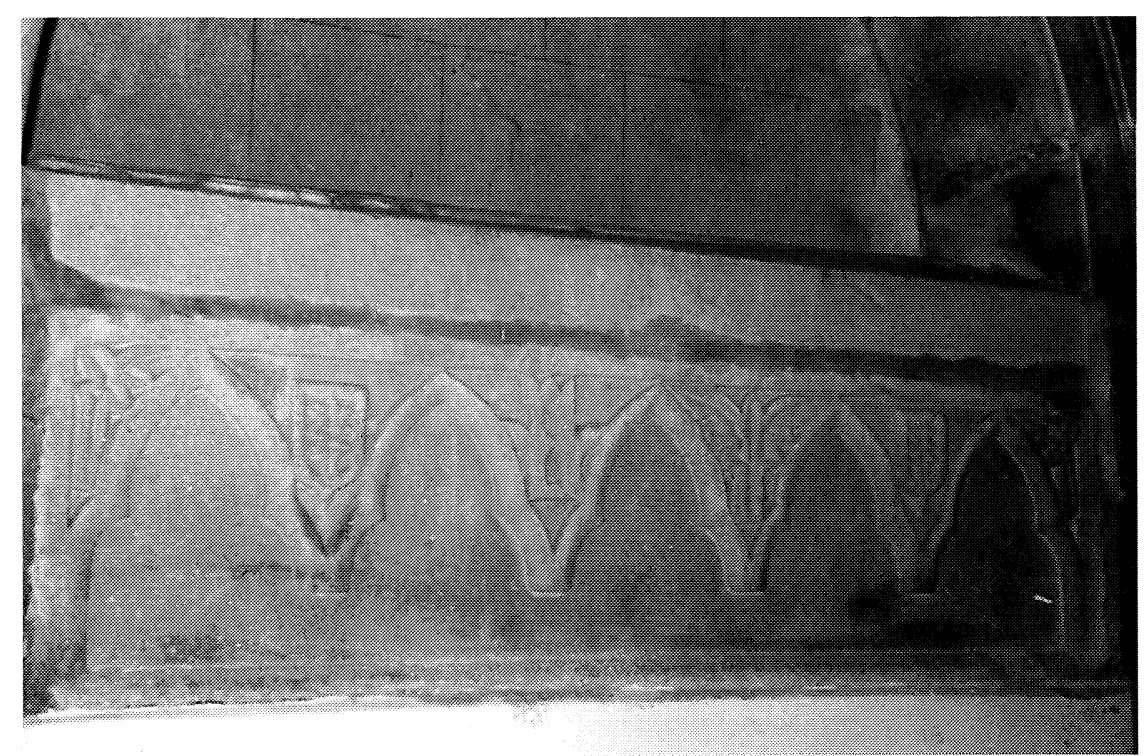

Figura 12.

En medio de ambos arcosolios se hallaría la yacija de $\mathrm{D}^{\mathrm{a}}$ Constanza de Castro Osorio $(+1498)^{71}$, actualmente desaparecida si, se consideran como fidedignas las noticias aportadas por Donapetry entorno a una primitiva sepultura, que en 1611 se cambia por la que actualmente ocupa (Fig.13) y que entonces se encontraba vacía, en el altar mayor (lado del Evangelio $)^{72}$. El sepulcro que ocupan los restos actualmente se halla en la nave, en el lado del Evangelio. Es un sepulcro exento, sin arcosolio, aunque por razones de espacio se aproximó al paramento mural. La yacija presenta

${ }^{71}$ Señora de Silán (Murás, Viveiro) y desposada con Ruy Díaz de Andrade, señor de San Pantaleón de las Viñas (Betanzos), que muere en la toma de Granada. Su hijo fundó la iglesia de los Remedios de Betanzos, a comienzos del S.XVI. Sobre esta dama y la verificación de su sepulcro, v. DONAPETRY IRIBARNEGARAY, J.: Historia ... pp. 178179. Un estudio más reciente, revela la genealogía de la Beata, así como documentos alusivos a su figura (testamento entre ellos), ha sido elaborado por PARDO DE GUEVARA Y VALDÉS, E.: «¿Quién era la Beata Doña Constanza de Castro? Notas críticas entorno a la discutida filiación de un personaje gallego del Siglo XV», en Estudios Mindonienses (en prensa).

${ }^{72}$ DONAPETRY IRIBARNEGARAY, J.: Historia ... p. 178.

"CUADERNOS DE ESTUDIOS GALLEGOS", Tomo XLIV, Fascículo 109, Santiago 1997. 


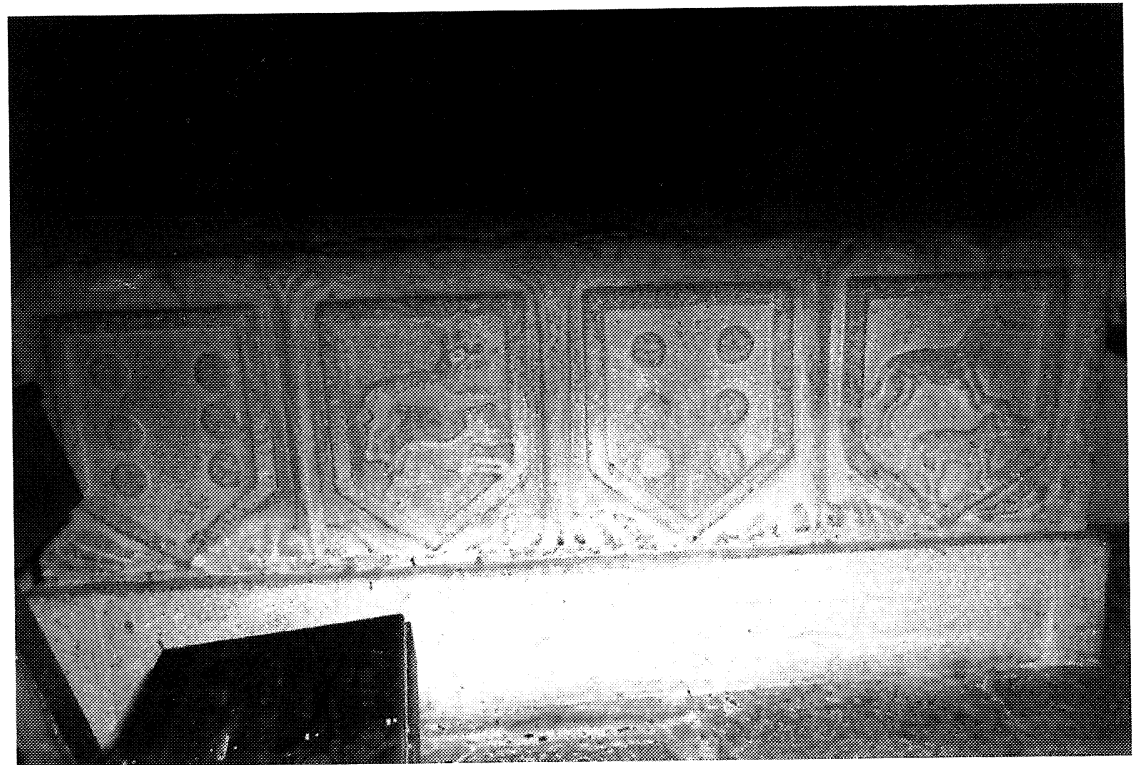

Figura 13.

las divisas de los Castro, en la variante portuguesa ${ }^{73}$, y Osorio, con los seis roeles y los dos lobos. En la tapa bajo el escudo de los Osorio, se observa el relieve de una espada, un dato más a favor de la hipótesis de Donapetry, acerca de la ocupación de un sepulcro que originariamente no era el suyo $^{74}$. Se trata pues de una pieza reutilizada pero probablemente el citado cenotafio pertenecía a algún miembro masculino de la misma familia que $\mathrm{D}^{\mathrm{a}}$ Constanza, puesto que presenta espada bajo el emblema, según el estudio de E. Pardo de Guevara ${ }^{75}$.

Por otra parte, el sepulcro presenta en la parte inferior de sus testeros una cabeza humana que se apoya sobre el pavimento, semejante a las empleadas para decorar la línea de imposta en el crucero o en el sepulcro

${ }^{73}$ Sobre la variante portuguesa en contraposición a la castellana del emblema de los Castro, v. PARDO DE GUEVARA Y VALDÉS, E.: «Doña Isabel de Castro: Apuntes críticos sobre su discutida filiación», en Hidalguía. Instituto «Salazar y Castro» (C.S.I.C.), 1985, pp. 421-442. p.431 para la nota.

${ }^{74} \mathrm{La}$ inscripción que se lee en la pared «GENERE, VIRTUTE AC SANCTITATE ILLUSTRISIMA».

${ }^{75}$ PARDO DE GUEVARA Y VALDÉS, E.: ¿Quien era la Beata...

"CUADERNOS DE ESTUDIOS GALLEGOS", Tomo XLIV, Fascículo 109, Santiago 1997. 
de la capilla de San Ildefonso, pero podría cuestionarse su pertenencia al sepulcro, si tenemos en cuenta el traslado y reforma posterior del mismo. Para esta pieza adjudicamos una cronología aproximada al llamado taller lucense II por C.Manso Porto (1400-1415) ${ }^{76}$.

En otro orden de cosas, el arcosolio que ocupaba su sepulcro originariamente, es de directriz apuntada, se decora con puntas de diamante y en el arranque de dicho arco aparecen las figuras de dos plañideras, una con expresión de «dolor contenido» (M.Núñez), sin signos de desesperación ${ }^{77}$, mientras, la otra, mesándose los cabellos, en gesto de dolor, expresión de «dolor desatado» (M.Núñez) ${ }^{78}$. La idea de combinar ambas no es infrecuente, y de hecho en algunas propuestas de sarcófagos castellanas se tiende a disponer, en un efecto contraste, el dolor concentrado y el dolor exteriorizado. En el primer caso, la muerte no es desesperación sino estado transitorio, en el segundo caso la muerte es, por el contrario, es la necesidad de alcanzar una inmortalidad social, para no quedar relegado al olvido. De ahí, la prevención que en la España del Medievo hubo, con respecto a estas profesionales del planto ${ }^{79}$.

Este hastial Norte se horada con un rosetón de tracería gótica, muy semejante al que aparece en el paño central del ábside de San Francisco de Betanzos, con la diferencia que supone la sobriedad decorativa del vivariense, puesto que la decoración vegetal del brigantino desaparece y se sustituye por molduras de tres boceles separados por sendas escocias.

${ }^{76}$ MANSO PORTO, C.: «Convento de Santa María de Valdeflores de Viveiro», en Estudios Mindonienses 4, 1988, pp. 151-232. pp. 341-342 para la nota. v. además nota 74 de este artículo.

${ }^{77}$ Detrás de este concepto está la idea de gestus, lo que equivale a decir que el poderoso no suele exteriorizar sus sentimientos, según M. Núñez. v. NÚÑEZ RODRÍGUEZ, M.: «Muerte heroica, muerte caballeresca», en Archivo Español de Arte 1995, pp. 80ss.

${ }^{78}$ En este caso el gestus se troca en gesticulatio o expresión de un estado anímico no sujeto a parangón, puesto que estas plañideras o «profesionales del planto» no quedaban vinculadas a la familia sino que eran profesionales de un oficio a sueldo. v. NÚÑEZ RODRÍGUEZ, M.: «Muerte heroica, muerte caballeresca...

${ }^{79}$ Agradezco al Prof. Manuel Núñez esta indicación. v. NÚÑEZ RODRÍGUEZ, M.: «Muerte heroica, muerte caballeresca», en Archivo Español de Arte 1995, pp. 80ss.; IDEM: La idea de la inmortalidad en la escultura gallega (la imaginería del caballero. S.XIV-XV). Orense, 1985.

"CUADERNOS DE ESTUDIOS GALLEGOS", Tomo XLIV, Fascículo 109, Santiago 1997. 


\section{b) El hastial meridional o capilla de San Antonio.}

Por su parte el hastial Meridional se horada con una ventana mainelada de arquillos trilobulados ojivales y coronados por tracería tetralobulada. Este espacio también se configura como capilla funeraria, por la presencia de dos arcosolios, decorados con arquillos de medio punto ligeramente ojivales. Ambos acogen sendos sepulcros con tres escudos cada uno en su yacija. En el Suroriental presentan los muebles de los Galo, los Pardo y los Viveiro (Gallo, Aguila y tres ramas con el lema AVE MARÍA GRATIA PLENA DOMI(ni) en bordura), mientras el Suroccidental repite el escudo de los Viveiro en los laterales flanqueando a un emblema fajado.

Esta tipología de arcosolio la hallamos de nuevo un arcosolio en esta misma iglesia de San Francisco, en la capilla de San Ildefonso, y dos lucillos sepulcrales, que albergan los enterramientos de los Gaimóndez (Fig.14), cuyas yacijas fueron labradas en 1506 según el epígrafe de los mismas, en una capilla funeraria de la iglesia de Santa María de Viveiro, estudiados por M. Díaz Tie ${ }^{80}$. Asimismo se deben relacionar con los

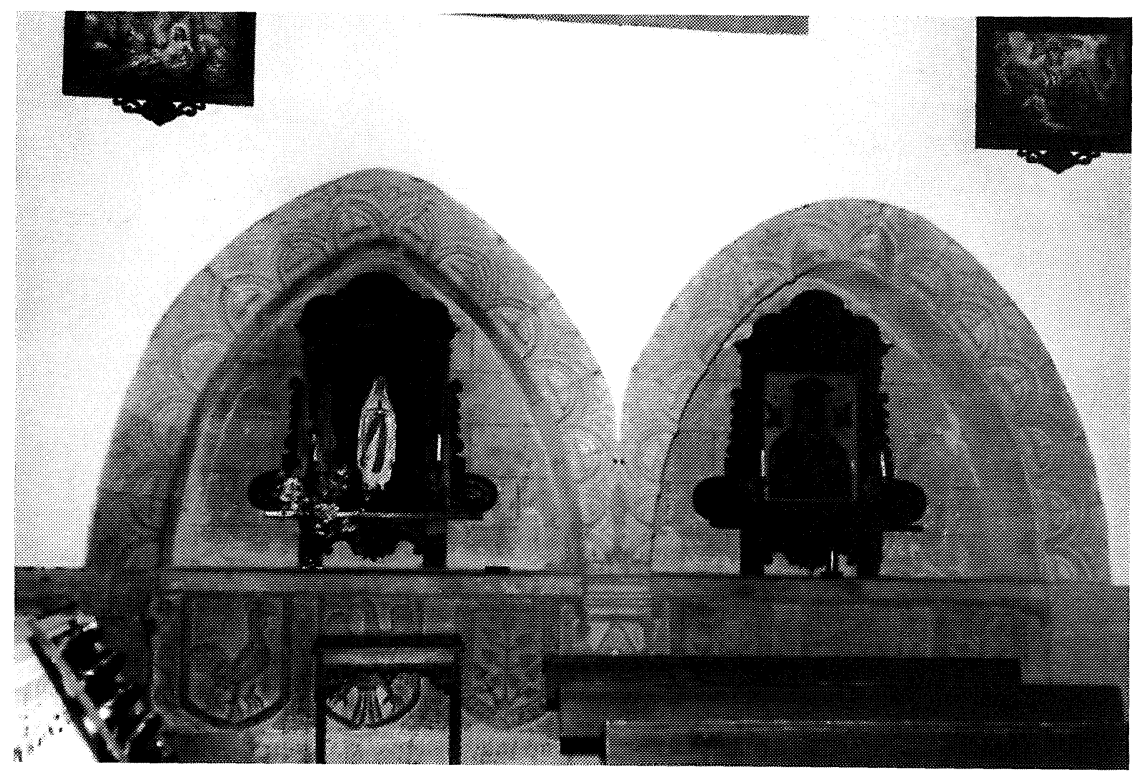

Figura 1.4.

${ }^{80}$ v. DÍAZ TÍE, M.: «La capilla funeraria de Lopo Afonso en la Iglesia de Santa María do Campo (Viveiro)», en Estudios Mindonienses 6, 1990, pp. 821-842.

"CUADERNOS DE ESTUDIOS GALLEGOS", Tomo XLIV, Fascículo 109, Santiago 1997. 
arcosolios de la nave del templo franciscano lucense (lado de la Epístola) en cuanto a su estructura, cuyos yacentes han sido datados por M. Núñez en el primer tercio del S.XV (ca. 1425-1430) ${ }^{81}$. Por su parte C.Manso liga el sepulcro de la capilla de San Ildefonso al taller lucense II, activo entre 1380-1415, merced al tipo de arquillos ciegos que lo decoran y la tipología de la capilla donde se ubica (columnas pareadas en el arco de ingreso, con capiteles decorados con hojillas lobuladas muy pegadas a la cesta y vueltas en la parte superior, motivos fantásticos en el interior, etc) ${ }^{82}$. En base a lo expuesto, consideramos que el sepulcro de la capilla de San Ildefonso y los dos arcosolios del hastial meridional del crucero de San Francisco forman parte de las obras emprendidas por el citado taller lucense II en Viveiro, tal como explica C.Manso, pero al que otorgamos una cronología de 1400-1415 en el caso a estudiar, puesto que en San Francisco de Lugo se hallaban trabajando en el último decenio del S.XIV, según M. Pérez. A él también atribuímos los arcosolios que ocupan las yacijas pos-

\footnotetext{
${ }^{81} \mathrm{El}$ arcosolio nos remite al taller que trabajó en los lucillos de las capillas absidiales del templo franciscano de Lugo, concretamente los que ocupan las sepulturas de Pedro Enríquez de Castro y el de su hijo Fadrique en la capilla absidial de la Epístola, mientras en la del Evangelio aparecen los arcosolios de Pedro Fernández de Bolaño y su hermano Rodrigo Alfonso de Saavedra, todos ellos realizados en el primer cuarto del S.XV. v. NÚÑEZ RODRÍGUEZ, M.: La idea de la inmortalidad... pp. 129-140. Considera que la factura de Pedro Fernández de Bolaño es necesario datarla ca. 1425-30, tras expresar su hijo, D.Fradique, su deseo de construir magníficos sepulcros en San Francisco de Lugo para albergar los restos de sus padres y hermanos. Asimismo, v. PÉREZ MARTÍNEZ, M.: Arquitectura mendicante: el ejemplo de San Francisco de Lugo. Tesis de Licenciatura inédita. Santiago, 1994. p.97-100. Agradezco a la autora la autorización para la consulta de este trabajo.

${ }^{82}$ MANSO PORTO, C.: «Convento de Santa María de Valdeflores de Viveiro», en Estudios Mindonienses 4, 1988, pp. 151-232. pp. 341-342 para la nota. En ese trabajo, C.Manso alude a la extensión del taller lucense II en la comarca vivariense, y así lo detecta trabajando en la iglesia conventual de Valdeflores (portada principal y arco de ingreso al ábside), en las parroquiales de San Pantaleón de Cabanas (Orol) y San Pablo de Riobarba (O Vicedo), y en Santo Domingo de Ortigueira. El taller procede de las obras Mendicantes de Lugo, desde donde se traslada a Santiago de Baamonde. Se especializa fundamentalmente en la elevación de capillas de planta cuadrada, a excepción de las franciscanas lucenses que son hemipoligonales, y columnas pareadas en el arco de ingreso, así como determinados motivos fantásticos (dragones entrelazados, flanqueando una cabeza humana, etc) y vegetales hojas lobuladas, muy pegadas a la cesta y vueltas en la parte superior). Para el ejemplo de Santo Domingo de Ortigueira, v. MANSO PORTO, C.: «El convento de Santo Domingo de Ortigueira», en Anuario Brigantino 12, 1989, pp. 209-220.
}

"CUADERNOS DE ESTUDIOS GALLEGOS", Tomo XLIV, Fascículo 109, Santiago 1997. 
teriores de los Gaimóndez en Santa María del Campo de Viveiro. La inscripción en la yacija de ambos que los cita como promotores directos de la obra en el año 1500, se refiere a la obra de la capilla donde se ubican y a las yacijas, mientras que los arcosolios fueron probablemente reaprovechados para su sepultura y quizás algunos de los elementos estructurales de la misma (nervios y arco de ingreso, no así los capiteles que parecen formar parte de la nueva obra).

\subsection{La capilla de San Ildefonso}

Así la capilla de San Ildefonso, abierta en el penúltimo tramo de la nave, lado de la epístola, una obra más de este taller lucense II, es el último recinto que analizaremos en el interior del templo. Su arco de ingreso es ojival, de gran luz, de sección cuadrangular y aristas chaflanadas, decoradas con tetrafolias de botón central y en la rosca, grueso bocel. Con estructura semejante aparece la capilla de los Gaimóndez en Santa María del Campo, aunque sin la decoración vegetal en el arco de ingreso. Los capiteles del arco de ingreso de esta capilla franciscana, con hojas lobuladas, de tallo central, pegadas a la cesta y vueltas en la parte superior, son características del taller lucense II, según las investigaciones de C.Manso. El interior se configura como un recinto de planta cuadrada, cubierto por bóveda de crucería, en la que los nervios voltean de un ángulo al opuesto, dos a dos. Presentan sección prismática moldurados en bocel recorrido por junquillo en el intradós mientras la rosca presenta una escocia, por lado. La clave recibe decoración de flor con pétalos estriados y pinjante central. Nervios con su molduración y esta clave se repiten también en la capilla de los Gaimóndez ya mencionada.

Los capiteles también reciben decoración alusiva al hombre que cae en el pecado (una sirena-ave con el rostro barbado en el capitel occidental entrego, en el ángulo con el arco de ingreso; en el frontero, dos dragones aparecen afrontados, en actitud de morder el hocico al contrario, y una cabeza humana permanece debajo del cuerpo de ambos animales y por último, en los capiteles entregos interiores observamos en el occidental, los dos dragones de nuevo afrontados pero esta vez flanquean una cabeza humana a la que le muerden las orejas, como símbolo de la tentación, y en el capitel entrego oriental presenciamos una escena de acecho a las espal-

"CUADERNOS DE ESTUDIOS GALLEGOS", Tomo XLIV, Fascículo 109, Santiago 1997. 
das de una sirena-ave por parte de un dragón). Este tipo de representación la hallamos en la geografía gallega desde el Protogótico, con la obra mateína del Pórtico de la Gloria, posteriormente retomado en Bonaval, y el resto de iglesias góticas gallegas, con especial énfasis en las Mendicantes. Sin embargo el tipo de dragón que aquí aparece representado, con el hocico alargado y cola que remata en palmeta, es característico de este taller lucense II, como se comprueba en el arco de ingreso de la capilla absidial del Evangelio del templo franciscano de Lugo, en el ábside de Santa María de Valdeflores de Viveiro y en esta capilla de San Francisco.

La capilla se ilumina a través de una ventana, abierta en el costado meridional, y conformada por dos arcos ojivales sencillos y limitados por mainel.

En este mismo costado meridional se ubica el arcosolio, sin inscripción, al que ya hemos hecho alusión (Fig.15). Cobija una sepultura, en cuya tapa se representa la cruz flordelisada. Presenta una variante del taller lucense II, al decorar su rosca con un friso de arquillos de medio punto ligeramente apuntados, coronado por una orla de puntas de diamante a modo de chambrana. Todo se remata con dos boceletes separados

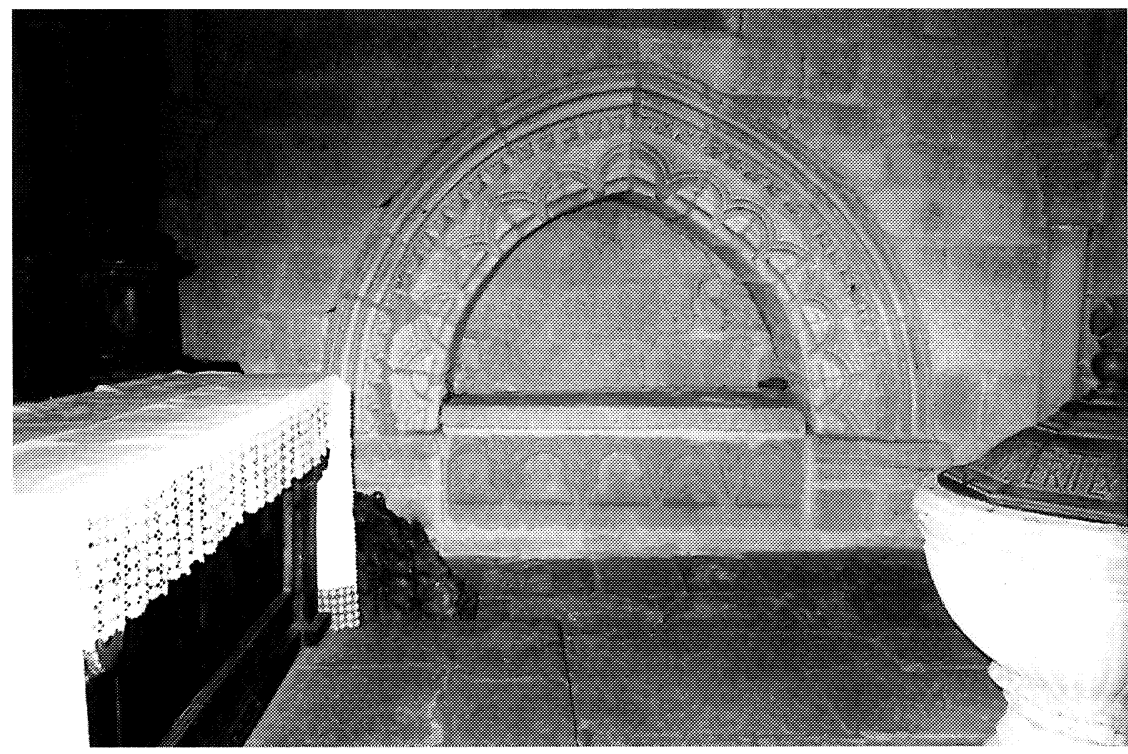

Figura 15.

"CUADERNOS DE ESTUDIOS GALLEGOS", Tomo XLIV, Fascículo 109, Santiago 1997. 
por sendas medias cañas y bordeado por un junquillo ${ }^{83}$. Una línea de imposta, sobre la que se apoya el salmer del arco remata en una cabeza humana, al igual que aparecía en el crucero, y como se puede apreciar en la capilla absidial del Evangelio de San Francisco de Ourense, y posteriormente en el crucero de San Francisco de Lugo y en el ábside de Santa María do Azougue y la capilla absidial de la Epístola de Santiago, ambas en Betanzos. El frente de la yacija se decora con una serie de arquillos de herradura peraltados, cuyos salmeres se decoran con hojas de lis, y el conjunto se inscribe en una orla de zig-zag. Nos remite a un modelo semejante al que ya aparecía en otro sepulcro del hastial septentrional del crucero, en cuya tapa se observa una cruz flordelisada.

Otra lauda en el pavimento presenta un escudo con un ciervo y tres flores de lis como muebles, y una inscripción «FERNAN(do) ALFEIRAN. $\mathrm{V}(\mathrm{i}) \mathrm{C}(\mathrm{o}) \mathrm{SO} »^{84}$. Desconocemos más datos de este personaje, aunque en la documentación, desde el siglo XV, se hace referencia a diversos personajes de la familia (tal es el ejemplo de Fernando Baño Alfeirán año de $1494)^{85}$, sin embargo hasta el momento no hemos hallado algún dato significativo que nos ayude a identificar al personaje inhumado bajo esta lauda.

${ }^{83}$ Esta variante es la que también hallamos en los arcosolios de Santa María del Campo, donde se albergan las sepulturas de los Gaimóndez.

${ }^{84}$ v. VÁZQUEZ CHAO, M.: «Correcciones al artículo $n^{\circ} 8$ de Cuadernos del Museo Mindoniense 1985». Viveiro, s.a.

${ }^{85}$ «1492, noviembre 18, Madrid. Los Reyes Fernando e Isabel ordenan a Fernando Cerón, corregidor de Viveiro, atienda y decida la causa presentada por Lope Núñez de Montenegro, vecino de Galdo, diciendo que Juan Cerva, hijo de Fernando Cerva, había sido acusado ante Pedro de Collazos, alcaide de la fortaleza de Moeche, a quien lo había cometido los alcaldes mayores de Galicia, de ciertos crímenes por los que estaba sentenciado a pena de muerte, y ruega que dicho corregidor obligue a Fernando Baño Alfeirán a que presente el encartamiento de la cuasa, a lo que oponía dilación por enemistad con el citado Núñez de Montenegro». Archivo General de Simancas. Registro del Sello, XI1494, fol.112. Por cita en GARCÍA ORO, J.: «Vivero y la familia de los Pardo de Cela», en Estudios Mindonienses 4, 1988, pp. 151-232. p. 204 para la nota.

"CUADERNOS DE ESTUdIOS GALLEGOS", Tomo XLIV, Fascículo 109, Santiago 1997. 


\subsection{La obra del «coro de çima»}

El coro alto, en los templos Mendicantes gallegos de la Edad Media aparece a finales del S.XV. Debemos otorgarle a Viveiro y al templo de Terciarios regulares de San Martín de Villaoriente (Mondoñedo), la primacía en la elevación de este espacio en los templos mendicantes gallegos, puesto que, en el mencionado documento vivariense de 1498, se alude a una obra ya iniciada: «(...) et otras çiertas obras estan començadas e espeçialmente el altar mayor e coro de çima» ${ }^{86}$, puesto que el coro alto de Santo Domingo de Ribadavia data de $1777-1778^{87}$, y la obra para el coro alto de San Francisco de Betanzos, la encontramos datada por inscripción (año de 1501) y fue realizada con la autorización del mismo fraile, Juan Carlín, Ministro Provincial de la Orden franciscana (en la rama conventual) en este momento ${ }^{88}$.

No obstante, la existencia de este dato de 1498 , no nos permite saber en que momento había comenzado la obra, impidiéndonos ir más allá.

${ }^{86}$ VILLAAMIL Y CASTRO, J.: Iglesias gallegas en la Edad Media. Madrid, 1904, pp.333-339. Expone la evolución del coro alto en las iglesias gallegas de la Edad Media. Considera este autor que el coro alto se remonta a mediados del S.XV en Galicia. Proporciona entre otros el dato de la existencia del coro alto de San Martin de Villaoriente (Mondoñedo), por la referencia de un testador que ordena ser inhumado junto a las escaleras del coro. Sin embargo en nuestra opinión podría referirse a las escaleras de acceso al coro bajo. p. 339 para la nota.

${ }^{87}$ MANSO PORTO, C.: Arte gótico... T.I. p.249 para la nota.

${ }^{88}$ FRAGA SAMPEDRO, $\mathrm{M}^{\mathrm{a}} \mathrm{D}$.: Arquitectura de los frailes Menores conventuales en la Edad Media gallega (S.XIII-XV). Tesis doctoral. Departamento de Historia del Arte, Facultad de Geografía e $H^{a}$. Santiago, 1995. En Italia este coro alto, a modo de tribuna ya aparecía en la segunda mitad del S.XIII, en España debemos esperar a finales del S.XV o principios del XVI para asistir a su aparición. Ofrece un estudio del nacimiento y evolución del coro en los conventos de clarisas BRUZELIUS , C.A.: «Hearing is Believing: Clarissan Architecture, ca. 1213-1340», en Gesta vol.XXXI, nº4, 1992, pp.83-91. Para el caso gallego v. VILLAMIL Y CASTRO, J.: Iglesias gallegas en la Edad Media. Madrid, 1904; FRAGA SAMPEDRO, $M^{\mathrm{a}}$ D.: «El convento medieval de Santa Clara de Santiago», en Oito Séculos de Claridade. Catálogo de la Exposición conmemorativa del VIII centenario del ancimiento de Santa Clara. Santiago, 1994. (en prensa).

En Portugal, sin embargo hallamos el coro alto con anterioridad en los templos Mendicantes. Así se atestigua la elevación de este espacio en el templo franciscano de Porto, a finales del S.XIV, con una aportación regia de Fernando I, para las obras en el edificio. v. FRAGA SAMPEDRO, M ${ }^{\mathrm{a} D}$.: Arquitectura franciscana en la antigua Custodia de Coimbra de los frailes Menores (S.XIII-XIV). Tesis de Licenciatura inédita. Santiago, 1992. pp. 124

"CUADERNOS DE ESTUDIOS GALLEGOS", Tomo XLIV, Fascículo 109, Santiago 1997. 


\subsection{Las reformas en época moderna}

Nuestro objetivo es el estudio del templo medieval, sin embargo estimamos necesario hacer una breve alusión a la trayectoria posterior del templo, que ha transformado, aunque en pequeños matices, el antiguo aspecto medieval.

Desde finales de la Edad Media el templo franciscano sufre una serie de reformas que culminarán en el S.XVII (ya en el documento de 1498 se hablaba de la necesidad de realizar reformas en el templo y convento franciscanos, sobre todo en la sacristía y coro de «çima» cuya obra estaba empezada, entre otros lugares del convento). Dos siglos más tarde, se transforma la nave medieval en una nave cubierta con bóveda de cañón de lunetos, sustentada por pilastras ${ }^{89}$. Para dejar constancia del momento en que se erigió la obra, se labró un epígrafe en la última pilastra de la nave, lado del Evangelio:

HIZOSE ESTA OBRA DE LOS VI
ENES DE CATALINA GRANDIA DE
LABRADA DISTRUBUIOLO DON
JUAN LERIN CORREGIDOR DESTA VILLA
POR SU MAGESTAD. Y GUARDI
AN EL PADRE FRAI PEDRO SOMU
HANO LETOR JUBILADO. AÑO 1657.

Ya en el S.XVIII, se sustituyó el armazón de madera del crucero por la actual cúpula, financiada con dos mil ducados, en 1725, por el obispo de Mondoñedo, Fr. Juan Muñoz y Salcedo ${ }^{90}$. Posteriormente (año 1741) se les concedió a los Terciarios seglares franciscanos la construcción de una capilla propia, la capilla de la Orden Tercera, en la nave, en el lado de la Epístola, entre las capillas de San Ildefonso y San Antonio ${ }^{91}$. Asimismo

\footnotetext{
${ }^{89}$ La obra de esta bóveda fue realizada por el maestro de obras Antonio Rodríguez Maseda, por encargo del P. Guardián Pedro Somuhano, como veremos en líneas posteriores. v. DONAPETRY IRIBARNEGARAY, J.: Historia... p. 121.

${ }^{90}$ DONAPETRY IRIBARNEGARAY, J.: Historia ... p. 121.

${ }^{91}$ IBIDEM, p. 123.
}

"CUADERNOS DE ESTUDIOS GALLEGOS", Tomo XLIV, Fascículo 109, Santiago 1997. 
en el mismo siglo, se abrió una puerta en el arcosolio que ocupaba el sepulcro de Constanza de Castro, en 1775, para dar paso a. la nueva sacristía ${ }^{92}$.

Otras reformas se llevaron a cabo en el templo en época moderna como fueron la reconstrucción del piso superior de la fachada y la torre-campanario, de las que hablaremos en el análisis exterior del edificio.

\subsection{El exterior del templo}

El exterior del templo, en su cabecera (Fig.16), guarda la estructura afín a otros templos medievales de esta Orden: la diferente gradación de volúmenes, con el ábside, máximo exponente por su altura y su estructura más cuidada. Las presiones que ejerce la bóveda en el interior se contrarrestan con esbeltos contrafuertes, que disminuyen su superficie en altura, y reseñan los diferentes niveles por medio de un chaflán. Dos líneas de resalto señalan asimismo el adelgazamiento en altura, salvo en los estri-

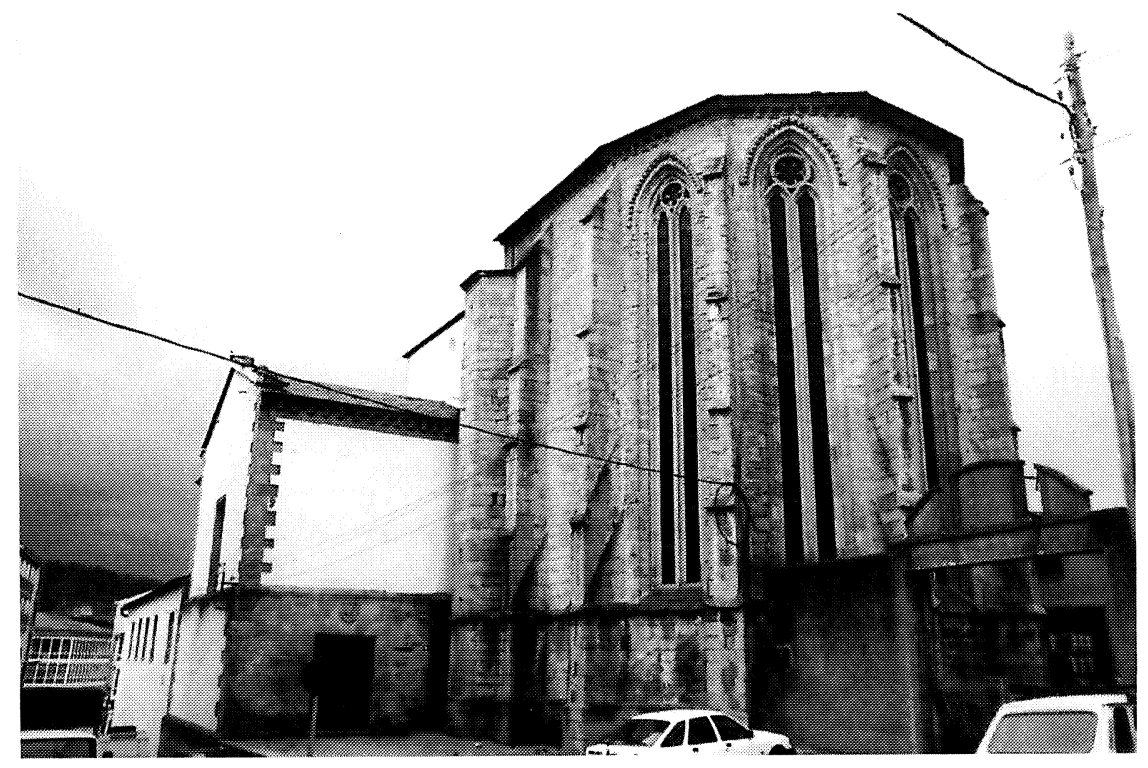

Figura 16.

${ }^{92}$ IBIDEM, p. 121.

"CUADERNOS DE ESTUDIOS GALLEGOS", Tomo XLIV, Fascículo 109, Santiago 1997. 
bos correspondientes al arco de ingreso, que tan sólo presentan uno, puesto que debido a su función de neutralizar todas las presiones, presentan mayor grosor. Llama la atención en uno de estos chaflanes la figura de un perro caquético, quizás un galgo, tal como aparece la figura de un perro en uno de los contrafuertes (noreste) del templo dominicano de Lugo, así como en otro estribo del claustro franciscano de Ourense; y por último junto a un jabalí y dos leones, símbolos de Fernán Pérez de Andrade y de su esposa, Sancha Rodríguez, en la iglesia franciscana brigantina.

En el lienzo mural de la Epístola se descubre en alzado la ya citada torrecilla de planta hemihexagonal, iluminada en diferentes niveles a través de ventanas ojivales.

Las ventanas se cubren con chambranas decoradas con puntas de diamante, tal como aparecen en otros templos mendicantes, como es el ejemplo de San Francisco de Betanzos, los templos mendicantes lucenses y el franciscano de Pontevedra. El alféizar de la ventana es destacado y se prolonga por los contrafuertes y los paños sin ventanas, como también aparece en otros templos mendicantes. En la cornisa los canecillos presentan perfil en nacela decorados con doble bocel, no sólo en el espacio del ábside sino que también los encontramos en todos aquellos espacios medievales del templo, que no han sido reformados.

Los brazos del crucero destacan también en alzado. Al brazo meridional se posibilita el acceso desde el exterior a través de una puerta moderna, aunque en ella se localiza el escudo medieval de los Galo sobre las ramas de los Figueroa. También, y en menor altura, destaca la capilla medieval de San Ildefonso en la nave, con contrafuertes en los ángulos. A continuación se ubica la torre campanario, donde una inscripción (actualmente muy deteriorada) aludía a la cronología y al P. Guardián, fr.Blas de Carabeo, bajo cuyo mandato se emprendió la obra de 1682, encargada al maestro Antonio Rodríguez Maseda ${ }^{93}$. Actualmente está muy deteriorada y ello dificulta la lectura, pero en cualquier caso es ya posterior a la época que estamos tratando y se engloba dentro de las reformas modernas del convento.

Tampoco la fachada del templo conserva todos sus elementos medievales, sin embargo podemos acceder a una reconstitución hipotética fácilmente. Se conforma por tres calles, divididas por los contrafuertes que

\footnotetext{
${ }^{93}$ DONAPETRY IRIBARNEGARAY, J.: Historia ... p. 120.
} 
enmarcan el cuerpo de la portada principal. Las calles laterales estaban ocupadas por las capillas de San Luis, en el lado derecho de la fachada, y de San Juan o del Alba, a la izquierda. Ambas se atribuyen a un origen gremial de las cofradías de los mareantes y pescadores de Viveiro ${ }^{94}$. Las reformas de época contemporánea, con la creación de la escalinata de acceso, ocultaron la parte inferior de las capillas, dejando patente el desnivel que existía entre una y otra. La fábrica de ambas nos remite a los años finales del S.XIV, por el cotejo con la puerta de acceso al claustro, la portada de la sacristía y, tal vez un poco posterior, la portada de San Francisco de Lugo que repite el mismo motivo en zig-zag datada a comienzos del S.XV por M.Pérez ${ }^{95}$ (con variaciones que supone el empleo de chambrana de puntas de diamante y rematado por nacela, bocel y filete en la capilla septentrional).

La portada, por el contrario, parece algo anterior a esta fecha y labor de otro taller. Se configura con arco de medio punto de directriz ligeramente apuntada, recorrido por aquivoltas, que descansan en dos capiteles por lado. Éstos se decoran con motivos vegetales, que recuerdan las hojas de ejes perlados mateínas, pero en este caso muy esquematizados, fruto de un taller local. Se coronan con cimacios ornamentados con roeles. $\mathrm{La}$ factura y decoración de los capiteles, así como la molduración de este arco nos pone en contacto con otros ejemplos de la arquitectura Mendicante gallega, algunos más tempranos. Así el tipo y la decoración de los capiteles se relaciona con los de la portada de San Francisco de Pontevedra y con los capiteles del costado Oeste en el segundo pilar de las naves (Epístola y el Evangelio) en Santo Domingo de Bonava ${ }^{96}$. Estas afinidades, en particular con el templo pontevedrés remonta a una cronología aproximada del tercer cuarto del S.XIV. Por documentación gráfica (imágenes dieciochescas y fotografías de principios de siglo) advertimos la existencia de un pórtico que cobijaba esta portada ${ }^{97}$.

${ }^{94}$ DONAPETRY IRIBARNEGARAY, J.: «Las capillas de San Luis y del Alba del convento de San Francisco de Vivero», en Boletín de la Comisión de Monumentos de Lugo T.II, 1945, 109-111.

${ }^{95}$ PÉREZ MARTÍNEZ, M.: Arquitectura mendicante: el ejemplo de San Francisco de Lugo. Tesis de Licenciatura inédita. Santiago, 1994. pp. 95-96.

${ }^{96}$ C.Manso atribuye una cronología de finales del S.XIII para estos capiteles de Bonaval. v. MANSO PORTO, C.: Arte gótico... T.I., pp. 165-166.

${ }^{97}$ CHAO ESPINA, E.: «Iglesia parroquial de Santiago de Vivero (antigua conventual de San Francisco)», en Abrente 11, 1979, pp.23-36, lám. s.n.

"CUADERNOS DE ESTUDIOS GALLEGOS", Tomo XLIV, Fascículo 109, Santiago 1997. 
En el piso superior se reformó en época moderna pues amenazaba ruina ${ }^{98}$. Desapareció entonces el piso superior medieval, aunque siguiendo la misma tipología que tendría entonces, excepto la ventana bajo frontón, de estructura moderna, (en el lugar de un rosetón o ventanal ojival como es el esquema característico de los templos mendicantes gallegos). La cubierta a dos aguas, acoge en la antefija una cruz griega.

Por último cuatro contrafuertes, dos a dos se colocan en los ángulos de la fachada para reforzar los paramentos frente a las presiones de la cubierta, que durante la Edad Media era de madera (la actual es una bóveda de época moderna). Desde el claustro todavía se pueden apreciar los contrafuertes medievales de la nave, lo que nos permite afirmar la existencia de seis tramos medievales en la nave.

\section{3.- EL CONVENTO MEDIEVAL: OTROS ASPECTOS DEL EDIFICIO MEDIEVAL}

Son escasos los restos que se conservan del edificio conventual (la sala capitular y dos puertas, una de acceso a la iglesia, otra de entrada al recinto conventual flanqueando la fachada del templo), sin embargo éstos junto con la documentación conservada y el cotejo con otros conventos Mendicantes permiten llegar a establecer una cronología.

La sala capitular (Fig. 17) se ubica en el ala Norte del claustro, al igual que en Lugo y Ourense. No es una localización común a todos los conventos de la Orden, pero los frailes siguiendo el comportamiento habitual de sus construcciones, reflejan una gran flexibilidad en el momento de ubicar sus dependencias, todo en aras de la funcionalidad y adaptación al espacio disponible ${ }^{99}$. Se conservan tres arcos de la primitiva sala capitular medieval, que probablemente estaría integrada por dos más, dado que todavía se observa en la rosca de los dos arcos, sendos fragmentos de enjutas de otros dos.

\footnotetext{
${ }^{98}$ Obedece al igual que la torre campanario a las obras emprendidas en 1682 por el maestro de obras Antonio Rodríguez Maseda a encargo del P. Guardián, fr.Blas de Carabeo. v. DONAPETRY IRIBARNEGARAY,J.: Historia... p. 120.

${ }^{99}$ CUADRADO SÁNCHEZ, M.: «Arquitectura franciscana en España. (Siglos XIII y XIV)» en Archivo Iberoamericano LI, 1991, no 203-204, pp.479-552. p.532 para la nota.
}

"CUADERNOS DE ESTUdIOS GALLEGOS", Tomo XLIV, Fascículo 109, Santiago 1997. 


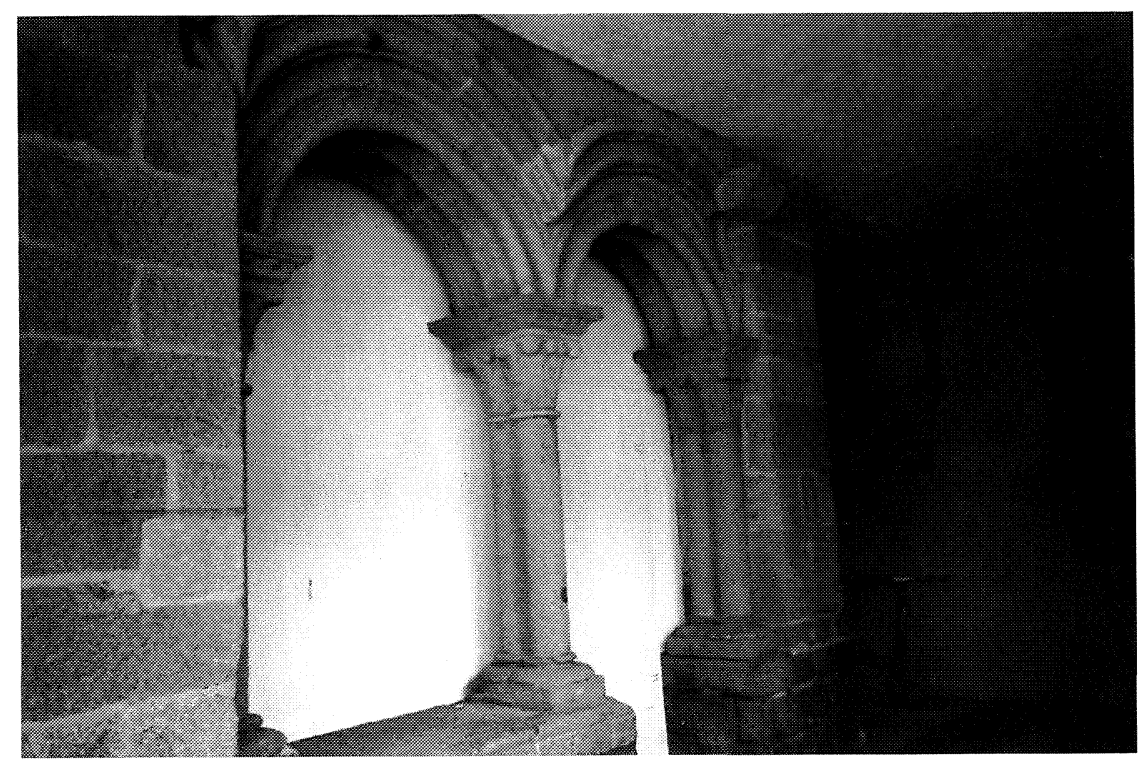

Figura 17.

Los arcos se molduran con tres boceles separados por sendas escocias en el intradós, molduración que se repite en la rosca. La misma organización la hallamos en otras salas capitulares franciscanas, como son la lucense y la de Terciarios regulares de San Francisco de Montefaro.

Los arcos se sustentan con columna pareadas monolíticas, con capiteles de perfil tronco-cónico, decorados con hojas alargadas (paralelinervias) y cruzadas diagonalmente formando motivos geométricos y rematadas en bolas en dos pisos, algunas con eje perlado, otras hojas son de helecho y rematan también en bolas (circidios), flores de lis estilizadas. Todos ellos presentan astrágalo moldurado en junquillo y los cimacios, en nacela rematada por un junquillo. Ésta se decora con motivos de zig-zag, veneras, rosetas. Las basas reposan sobre estrecho plinto cuadrangular. Por su parte todo el conjunto se asienta en un alto podium.

Por sus características, capiteles y cimacios se relacionan con los capiteles de la portada occidental del templo, así como con la portada de San Francisco de Pontevedra. Ello supone otorgarles una cronología del tercer cuarto del S. XIV.

"CUADERNOS DE ESTUDIOS GALLEGOS", Tomo XLIV, Fascículo 109, Santiago 1997. 
Los dos canes conservados, sobre estos arcos, nos llevan a pensar en el empleo de la madera, para cubrir las cuatro galerías del claustro ${ }^{100}$. Desconocemos la tipología de la cubierta del Capítulo, sin embargo estimamos probable también una cubierta de madera, como era habitual en esta dependencia.

La puerta que da acceso a la iglesia en el ala Este del claustro presenta un arco de ingreso trebolado destacado por molduración de dos junquillos que flanquean un listel (Fig.18). El arco se inscribe en otro de medio punto decorado con arquillos de medio punto entrelazados, en cuyas enjutas aparecen animales en bajorelieve muy tosco (dragones, unicornios, perros y pájaros), en una factura que los relaciona con el arco de ingreso a la sacristía en el interior del templo. El conjunto se remata con un bocel, junquillo y filete. Reposa en columnas monolíticas, de capiteles decora-

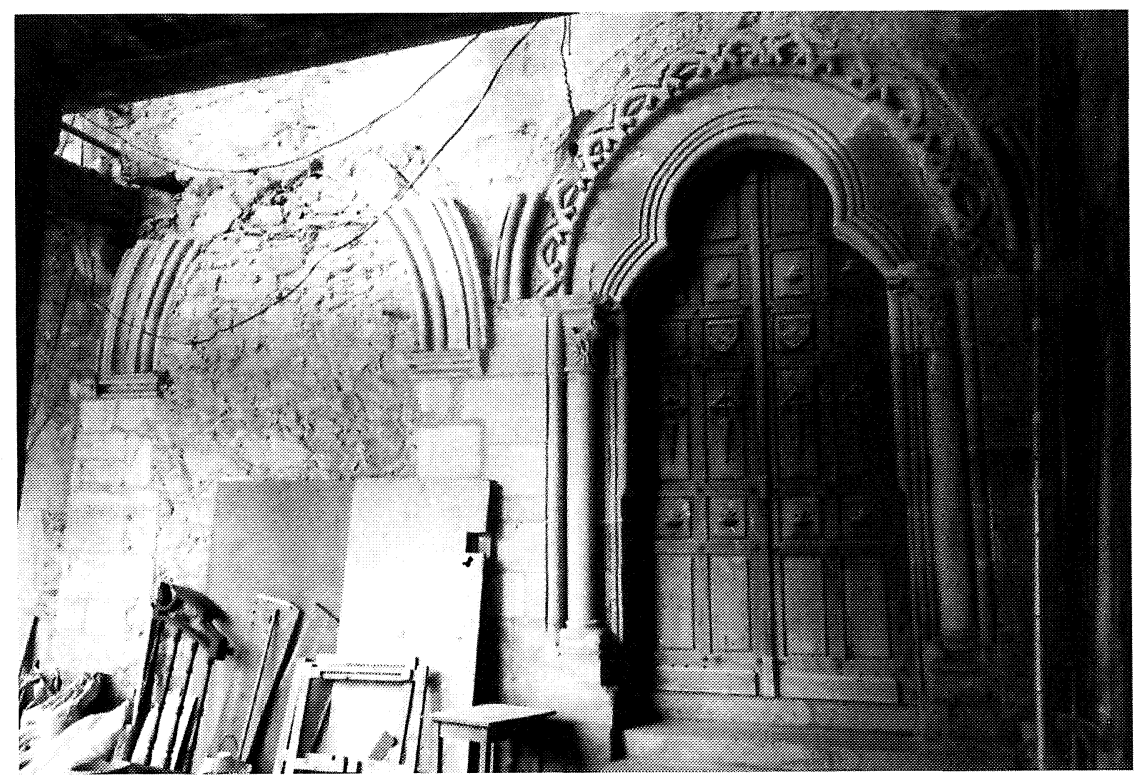

Figura 18.

${ }^{100}$ Las armaduras parhileras eran empleadas en la cubierta de claustros, transeptos y naves de la mayor parte de los recintos mendicantes gallegos. Se conservan restos en el transepto de San Francisco de Lugo, en el claustro de Viveiro, y más tempranamente en el templo dominicano de Belvís en Santiago. v. MANSO PORTO, C.: Arte gótico... T.II. p.586.

"CUADERNOS DE ESTUDIOS GALLEGOS", Torno XLIV, Fascículo 109, Santiago 1997. 
dos con hojas de roble de talla tosca, semejantes a las que aparecían en el crucero. Las basas se decoran con garras vegetales en los ángulos y se asientan sobre plintos cuadrangulares. Consideramos, a la vista de estas características, que esta puerta se englobaría dentro de las obras del tercer tercio de siglo XIV, cuando se llevaba a cabo la construcción de los hastiales del crucero.

La puerta que aparece a continuación, en esta galería Este, se encuentra tapiada actualmente. Estaba estructurada con arco medio punto moldurado en escocia flanqueada por sendos boceles en la parte interior de la rosca, y bocel flanqueado por junquillos en la parte externa. Se apoya en una línea de imposta que sale de la boca de una cabeza humana, en semejanza con el arcosolio de la capilla de San Ildefonso, o el sepulcro donde se inhumó la Beata Constanza de Castro. Correspondería pues al mismo taller que las mencionadas obras, ca. 1400-1415.

Resta por comentar la puerta de acceso al convento desde el exterior, al lado de la fachada de la iglesia. Se trata de un arco de medio punto, cuyo tímpano sin decoración se sustenta sobre sendas mochetas. La puerta da acceso a un pasillo que remata en otra de semejantes características, excepto en el óculo que la horada. Ambas puertas son de larga tradición ya desde época románica y su continuidad durante el gótico gallego nos impide una cronología concreta. Nuestra hipótesis es que pertenecían a la obra conventual de finales del S.XIII.

Como se ha dicho en líneas anteriores, las reformas del S.XVII nos dificultan el conocimiento de las otras dependencias medievales, así como su ubicación en el plano del recinto conventual. Sin embargo el mencionado documento de 1498, nos informa de la existencia de «muchas ofiçinas e hediçios del dicho monesterio estan viejas, caidas e disipadas, espeçialmente la sacrestia, spiçio, e refertorio y dormitorio, cozina e çimiterio (...)». Todas ellas construídas a lo largo de los siglos bajomedievales, sin que podamos determinar la fecha, aunque la documentación de mediados del S.XIV, con la reunión del Concejo con el obispo de Mondoñedo (año 1349), «eno moesteiro de San Francisco», nos permite suponer que las dependencias de primera necesidad (dormitorio, sala capitular, cocina, refectorio) ya se encuentran en uso, hipótesis que se afianza con la mención de la «rua de San Francisco» en un documento de donación de una:s casas vivarienses del canónigo Paulucho a la 
catedral mindoniense en el año $1333^{101}$. Ello nos hace suponer asimismo que el monasterio ya contaba con cierta estabilidad y proyección en la vida social de la villa, puesto que una calle lleva su nombre.

\section{4.- CONCLUSIONES}

Llegado este punto debemos hacer un balance de la actividad constructiva en este ejemplo de la Orden franciscana.

En primer lugar, dado la mención de una iglesia franciscana en la carta de 1293 del obispo mindoniense, podemos considerar la existencia de una primitiva iglesia o primer templo de los frailes en Viveiro, de la que no conservamos restos, tal vez porque fuese tan sólo un pequeño templo provisional, como emplearon los frailes en sus orígenes. En esta primera fase de instalación de los frailes, estimamos probable la elevación del convento entorno a un claustro, con sus dependencias de primera necesidad (capítulo, dormitorio, cocina, refectorio), o quizás su instalación en algún inmueble donado por particulares.

A una segunda fase constructiva obedece la elevación del ábside, dato que nos aporta el epígrafe del ábside (año 1344). El segundo tramo recto que antecede al ábside, así como la sacristía medieval, el crucero, el hastial Septentrional del mismo y las capillas de San Juan y San Luis pertenecen al siguiente período en la elevación del templo, probablemente ca. 1387 1400 , momento al que acaso se refieren los aludidos testamentos de $\mathrm{Al}-$ fonso Yáñez (año 1387) y María Rodríguez (1391). Probablemente es entonces cuando se remata la fachada y se construye la arquería de acceso a la Sala Capitular.

A continuación, ya dentro del S.XV, se construyen la capilla de San Ildefonso y el hastial meridional del crucero.

En esa ralentización de la empresa constructiva del templo, quizás haya influído el incendio que sufrió la villa en 1381, y, por otra parte, las guerras trastamaristas, que habían influído en la construcción del con-

\footnotetext{
101 «dou et offeresco para senpre aa dita Iglesia de Santa Maria para o Cabidoo dessa Iglesia as minnas casas et praça que eu ey en Viveyro, que estan enna rua que chaman de San Francisco» CAL PARDO, E.: «De Viveiro... p. 122, n $^{\circ} 42$.
}

"CUADERNOS DE ESTUDIOS GALLEGOS", Tomo XLIV, Fascículo 109, Santiago 1997. 
vento dominicano, como ya aludimos anteriormente. Ambos acontecimientos, probablemente retrasaron el curso de las obras en el templo franciscano.

Por último a finales del S.XV, se llevan a cabo obras de reparación del altar mayor y sacristía, así como la construcción del coro alto. Se emprenden asimismo reformas en el convento.

Por otra parte, la construcción franciscana vivariense parece un ejemplo claro de la aportación del estamento popular villa en la construcción del recinto conventual. Así hallamos constantemente la petición de inhumación por parte de personas no vinculadas al estamento noble, aunque éste también buscará el templo franciscano para su enterramiento, sobre todo a partir del S.XV, aunque ya en años anteriores seguía este comportamiento. Sin embargo, como una prueba de la adhesión del pueblo a los frailes de San Francisco, ya desde finales del S.XIII encontramos la acogida que éstos deparan a aquellos que han sido excomulgados, tal como se recogía en la documentación. Y esta fidelidad tendrán su reflejo en el arte, con la finaciación del ábside y mandas para la obra del convento, así como en la iconografía de carácter cinegético que se reproduce en la sacristía con motivos de apoyo, extraídos de la fauna local, sin duda de gran valor para el exemplum que los frailes utilizan en sus largas exposiciones, $\mathrm{y}$, sin duda, muy familiares para los vivarienses. 